\title{
Anorganski spojevi sumpora u ljudskom tijelu. I. Okso-spojevi.
}

DOI: $10.15255 /$ KUI.2016.048

KUI-44/2017

Pregledni rad

Prispjelo 6. prosinca 2016.

Prihvaćeno 22. veljače 2017.

\author{
S. Stanković i R. Kiralj* \\ Veleučilište u Bjelovaru, Trg Eugena Kvaternika 4, 43000 Bjelovar, Hrvatska
}

Ovo djelo je dano na korištenje pod Creative Commons Attribution 4.0

\begin{abstract}
\| Sažetak
Sumpor je nakon kalcija i fosfora najzastupljeniji element u ljudskom tijelu, gdje se nalazi u mnogobrojnim anorganskim i organskim spojevima, a u vrlo malim količinama i u elementarnom stanju. $U$ ovom pregledu prikazani su anorganski spojevi sumpora iz klase endogenih okso-spojeva u ljudskom organizmu, koji ponajprije nastaju enzimskim i neenzimskim biosintetskim putevima u stanicama ili izvanstaničnom prostoru. Opisani su sulfati, tiosulfati, $\mu$-disulfido-bis(trioksosulfati)(2-) (tetrationati), sulfiti, hidrogensulfiti, sulfonati i disulfiti najzastupljenijih metala u organizmu $\left(\mathrm{Na}^{+}, \mathrm{K}^{+}, \mathrm{Ca}^{2+}\right.$ i $\left.\mathrm{Mg}^{2+}\right)$ i sumporov dioksid. Anioni i $\mathrm{SO}_{2}$ jesu endogene neradikalske sumporove vrste koje se nalaze u znatnim koncentracijama u tjelesnim tekućinama, gdje imaju zasebne fiziološke, patološke, metaboličke, detoksikacijske i druge uloge. Međusobno su povezani metaboličkim putevima sumporovih spojeva. Dok je sulfatni ion redovit sastojak elektrolita i izvor sumpora, tiosulfatni ion ima brojne zaštitne funkcije i važan je metabolit, a anioni nastali reakcijom $\mathrm{SO}_{2}$ i vode također su važni metabolički međuprodukti. Novijim istraživanjima prepoznate su uloge sumporova dioksida kao nove signalne molekule i aniona $\mu$-disulfido-bis(trioksosulfata)(2-), kao metabolita koji se stvara tijekom upale crijeva. Istraživanja o opisanoj klasi sumporovih spojeva i njihovoj važnosti za ljudski organizam očito nisu završena i mogu još donijeti važne i neočekivane spoznaje.
\end{abstract}

\| Ključne riječi

Elementarni sumpor, sulfati, tiosulfati, tetrationati, sumporov dioksid, sulfiti

\section{Uvod}

Sumpor (engl. sulphur, fra. soufre, njem. Schwefel, tal. zolfo, šp. azufre, port. enxofre), simbol S (lat. sulphur), kemijski je element 16. skupine periodnog sustava (CAS registracijski broj: 7704-34-9, relativna molekulska masa $32,06)$, koji ima četiri stabilna izotopa s masenim brojevima od 32 do 36, dok su ostali nepostojani. ${ }^{1-3}$ Daleko najzastupljeniji je ${ }^{32}$ S, koji ujedno čini $95 \%$ ukupnog sumpora na Zemlji. ${ }^{1,2} \cup$ Zemljinoj kori sumpor nije znatnije zastupljen (260 ppm), ali se može relativno lako dobiti..$^{3,4}$ Osobito su bogata nalazišta prirodnog sumpora u Sjevernoj Americi, na Siciliji, u Francuskoj, Španjolskoj, Rusiji i Japanu. ${ }^{1,4,5}$ Prosječne koncentracije sumpora u slatkoj i morskoj vodi iznose otprilike 3,7 odnosno 905 ppm., ${ }^{4,6}$ Izuzev u elementarnom stanju, sumpor se može naći i u mnogobrojnim sulfidnim i sulfatnim mineralima kao što su pirit $\left(\mathrm{FeS}_{2}\right)$, halkopirit $\left(\mathrm{CuFeS}_{2}\right)$, sfalerit $(\mathrm{ZnS})$, kalcijev sulfat $\left(\mathrm{CaSO}_{4} \cdot 2 \mathrm{H}_{2} \mathrm{O}\right)$ i mnogi drugi. $^{4-7}$ Sumpor se u tlima nalazi u bitnim količinama (800 kg/ha), dok je njegova količina u biljci oko 0,1 \%. ${ }^{8}$ Za tla siromašna sumporom upotrebljavaju se sumporna gnojiva. Vulkanski plinovi sadržavaju sumporovodik $\left(\mathrm{H}_{2} \mathrm{~S}\right)$ i sumporov dioksid $\left.\left(\mathrm{SO}_{2}\right)\right)^{1,5}$

Elementarni sumpor je krutina svijetložute boje, bez mirisa i okusa, netopljiva u vodi. ${ }^{4}$ Sumpor se javlja u velikom broju alotropnih modifikacija, čak u njih oko $30 .{ }^{9}$ Najvažniji alotrop rompski sumpor ( $\alpha$-sumpor) građen je od prstenastih molekula koje sadrže 8 atoma sumpora u obliku

*Autor za dopisivanje: Dr. sc. Rudolf Kiralj e-pošta: rkiralj@vtsbj.hr krune. ${ }^{1,4,7}$ Rompski sumpor zagrijavanjem pri temperaturi $95,5{ }^{\circ} \mathrm{C}$ prelazi u drugi kristalni oblik tzv. monoklinski sumpor ( $\beta$-sumpor). U strukturi monoklinskog sumpora također su pronađene prstenaste molekule $S_{8}$. Te dvije modifikacije razlikuju se u načinu slaganja molekula $S_{8} u$ kristalnoj strukturi. Struktura molekule ${ }^{10} \mathrm{~S}_{8}$ prikazana je na slici 1 s pomoću molekulske grafike. ${ }^{11}$

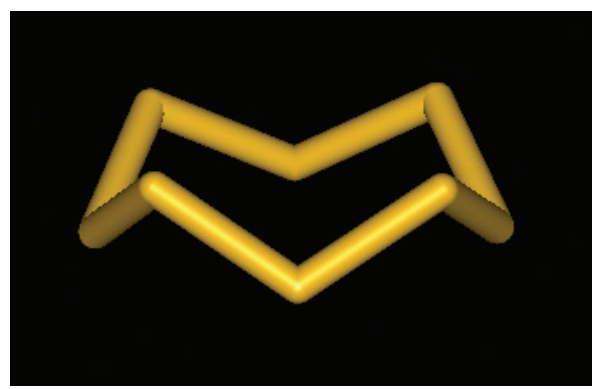

Slika 1 - Prikaz strukture molekule $\mathrm{S}_{8}$ (kruna)

Fig. 1 -Representation of the structure of the $\mathrm{S}_{8}$ molecule (crown)

Sumpor je kemijski reaktivan element. ${ }^{4,5} \mathrm{Na}$ zraku gori modrim plamenom dajući sumporov dioksid. Sastavni je dio velikog broja organskih i anorganskih spojeva u kojima najčešće ima i negativan (-II) i pozitivan stupanj oksidacije (II, IV ili VI).?

Sumpor se upotrebljava u poljoprivredi kao fungicid, u prehrambenoj industriji kao konzervans, za proizvodnju 
sumporne kiseline i drugih sumporovih spojeva, za vulkanizaciju guma itd. $1,4,5,7,12$

Sva živa bića imaju potrebu za sumporom. ${ }^{3}$ Nakon kalcija i fosfora, sumpor je najzastupljeniji element u ljudskom tijelu. ${ }^{13}$ Nalazi se u znatnim koncentracijama u ljudskim tkivima i stanicama (tablica 1).,

Tablica 1 - Količina sumpora u ljudskom tijelu

Table 1 - Amount of sulphur in the human body

\begin{tabular}{l|c}
\hline $\begin{array}{l}\text { Vrsta tkiva } \\
\text { Tissue type }\end{array}$ & $\begin{array}{c}\text { Količina } \\
\text { Amount }\end{array}$ \\
\hline $\begin{array}{l}\text { krv } \\
\text { blood }\end{array}$ & $0,18 \%$ \\
kosti \\
bones \\
jetra \\
$\begin{array}{l}\text { liver } \\
\text { mišići } \\
\text { muscles }\end{array}$ & $0,05-0,24 \%$ \\
\hline
\end{tabular}

U organizam se unosi hranom u obliku organskih i anorganskih spojeva. ${ }^{14}$ Glavni izvori sumpora su aminokiseline metionin, cistein i cistin (aminokiseline koje sadrže sumpor). ${ }^{3,15-17}$ Sumpor se iz anorganskih spojeva prilično slabo apsorbira, dok se sumpor iz organskih spojeva relativno dobro apsorbira u tankom crijevu. ${ }^{14,17}$ Višak sumpora izlučuje se iz organizma stolicom i urinom. ${ }^{18}$

Namirnice bogate sumporom su meso, riba, mlijeko, jaja, mahunarke i orašasti plodovi. ${ }^{16-18}$ Ukupna masa sumpora u 70 kg teškoj osobi je 140 g, dok je preporučeni dnevni unos (RDA vrijednost) oko $900 \mathrm{mg} .{ }^{3,18}$ Sumpor se u elementarnom stanju nalazi u krvi kao endogena tvar, gdje ga eritrociti reduciraju u sumporovodik bez sudjelovanja enzima. ${ }^{19}$

Taj je element potreban za formiranje kolagena i keratina, glavnih proteinskih komponenti koje pomažu u cijeljenju rana te su važne za opće zdravlje kože, kose, noktiju i vezivnog tkiva. ${ }^{15-17,20} \mathrm{U}$ ljudskom organizmu ima ulogu i u pravilnom razvoju hrskavice i tetiva i sastavni je dio jednog od najvažnijih antioksidansa glutationa (GSH), koenzima A (CoA) i metilsulfonilmetana (MSM). Nadalje, sumpor je sastojak nekih vitaminima (biotin, tiamin) i hormona (inzulin, hormoni adenohipofize). Potreban je i za detoksikacijske procese, koagulaciju krvi te za proizvodnju soli žučnih kiselina važnih u probavi masti.

Pomanjkanje sumpora vrlo je rijetko i moguće je u slučajevima nedovoljnog unosa bjelančevina. ${ }^{16,17}$ Niska razina sumpora u tijelu opažena je kod trihotiodistrofije (autosomna recesivna bolest, koja se manifestira krhkom kosom) i hiperhomocisteinemije (stanje nagomilavanja aminokiseline homocisteina $u$ organizmu). ${ }^{21,22}$

Sumpor se upotrebljava u terapiji kožnih bolesti kao što su akne, ekcemi, psorijaza, dermatitis. ${ }^{17,18}$ Osim toga, koristan je u liječenju alergijskih reakcija, reumatoidnog artritisa, recidivirajućih infekcija gornjih dišnih puteva, urinarnog i respiratornog trakta, glavobolje i mišićne napetosti.

\section{Endogeni okso-spojevi sumpora građeni od tetraedara $-\mathrm{SO}_{3} \mathrm{X}(\mathrm{X}=0, \mathrm{~S})$}

\subsection{Sulfatni anion, sastojak elektrolita u tjelesnim tekućinama}

Sumporna kiselina ili divodikov tetraoksosulfat (CAS registracijski broj: 7664-93-9, relativna molekulska masa $98,08)$ kemijske formule $\mathrm{H}_{2} \mathrm{SO}_{4}$, bezbojna je uljasta, korozivna i vrlo nagrizajuća tekućina, bez mirisa i jedan je od najvažnijih proizvoda kemijske industrije. ${ }^{23,24}$

Disocijacijom sumporne kiseline u prvom stupnju nastaje hidrogensulfatni ion $\left(\mathrm{HSO}_{4}^{-}\right)$, a u drugom stupnju sulfatni ion $\left(\mathrm{SO}_{4}{ }^{2-}\right): 25$

$$
\begin{gathered}
\mathrm{H}_{2} \mathrm{SO}_{4}(\mathrm{aq})+\mathrm{H}_{2} \mathrm{O}(\mathrm{l}) \leftrightharpoons \mathrm{HSO}_{4}{ }^{-}(\mathrm{aq})+\mathrm{H}_{3} \mathrm{O}^{+}(\mathrm{aq}), \\
\mathrm{HSO}_{4}{ }^{-}(\mathrm{aq})+\mathrm{H}_{2} \mathrm{O}(\mathrm{l}) \leftrightharpoons \mathrm{SO}_{4}{ }^{2-}(\mathrm{aq})+\mathrm{H}_{3} \mathrm{O}^{+}(\mathrm{aq}) .
\end{gathered}
$$

Vrijednosti $\mathrm{p} K_{\mathrm{a} 1}$ i $\mathrm{p} K_{\mathrm{a} 2}$ za sumpornu kiselinu iznose $-3,0^{24}$ odnosno 1,99 kod $25{ }^{\circ} \mathrm{C}$. ${ }^{26}$ Sumporna kiselina jedna je od najjačih kiselina, tj. potpuno disocira u prvom stupnju. ${ }^{24}$ Kod $\mathrm{pH}=7,4$ (pH-vrijednost krvi) vrsta koja prevladava je $\mathrm{SO}_{4}{ }^{2-}$ (više od 99,999\%), dok se udjel $\mathrm{HSO}_{4}{ }^{-}(\approx$ $0,0004 \%$ ) može zanemariti. Kod nižih vrijednosti pH, primjerice kod $\mathrm{pH}=6,9$ ( $\mathrm{pH}$ u mišićnim stanicama) ${ }^{27}$ i 6,3 (pH sluznice usne šupljine), ${ }^{28}$ kao u prethodnom slučaju, vrsta koja dominira je $\mathrm{SO}_{4}{ }^{2-}$ (više od 99,99\%), dok je udjel $\mathrm{HSO}_{4}{ }^{-}$vrlo malen i on iznosi približno 0,001 \% za $\mathrm{pH}=6,9$, a oko $0,005 \% \mathrm{za} \mathrm{pH}=6,3$.

Sulfatni ion najviše je oksidiran oblik sumpora. Struktura mu je tetraedarska, u kojoj je sumpor okružen s četiri atoma kisika koji tvore dvovalentni anion $\mathrm{SO}_{4}{ }^{2-} \cdot{ }^{29} \mathrm{U}$ metalnim sulfatima može se vezati na metalne katione kao premošćujući ligand. ${ }^{29}$ Primjerice, u kristalnoj strukturi bakrova(II) kompleksa formule $\left[\left(\mathrm{C}_{3} \mathrm{~N}_{2} \mathrm{H}_{4}\right)_{3} \mathrm{Cu}\right] \mathrm{SO}_{4}$ sulfatni anion premošćuje dva metalna kationa. ${ }^{30}$ Duljine veza S-O u anionu iznose od 146 do 149 pm, a vezni kutevi s vrijednostima od 108 do $111^{\circ}$ bliski su idealnom tetraedarskom kutu od $109,5^{\circ}$. U kristalnoj strukturi soli sulfata i hidrogensulfata s piperidinijevim kationom ${ }^{31}$ duljine veza S-O jesu od 146 do 150 pm, a vezni kutevi O-S-O su od 107 do 111. lako na anion utječu vodikove veze s kationom i hidrogensulfatom, njegova struktura gotovo je identična prethodnoj. Međutim tetraedarska struktura hidrogensulfata ponešto je deformirana zbog prisustva atoma vodika: tri sulfatne veze S-O duljina su od 145 do 146 pm, četvrta veza S-O $(\mathrm{H})$ 156 pm, a vezni kutevi O-S-O variraju u većem rasponu od 104 do $114^{\circ}$. Anion ima gotovo identičnu strukturu u kristalu hidronijeva hidrogensulfata, gdje su anion i kation povezani isključivo vodikovim vezama. ${ }^{32}$ Još značajnije odstupanje od pravilne tetredarske koordinacije opaženo je u kristalnoj strukturi sumporne kiseline: ${ }^{32}$ duljine dviju sulfatnih veza S-O iznose 143 pm, dok je duljina dviju $\mathrm{S}-\mathrm{O}(\mathrm{H}) 154$ pm. Vezni kutevi O-S-O nalaze se u većem intervalu od 105 do $118^{\circ}$. Očito je da međumolekulske sile u kristalu ponešto utječu na strukturu $\mathrm{H}_{2} \mathrm{SO}_{4}$ jer mikrovalnom spektroskopijom određena molekulska struk- 
tura sumporne kiseline pokazuje izrazitije odstupanje od pravilne tetraedarske koordinacije: ${ }^{26}$ duljine sulfatnih veza $\mathrm{S}-\mathrm{O}$ iznose $142 \mathrm{pm}$, a duljine veza S-O(H) $157 \mathrm{pm}$. Vezni kutevi O-S-O su u još većem intervalu od 101 do $123^{\circ}$.

Red veze je koristan pokazatelj raspodjele elektrona među atomima koji tvore kemijsku vezu. Red veze S-O jednostavno se može izračunati iz duljine veze S-O prema formuli koju su objavili Gillespie i Robinson, prema kojoj je jednostruka veza sumpor-kisik duljine 170 pm, a dvostruka $140 \mathrm{pm}:{ }^{33}$

$$
n(S-O)=\frac{15,65}{(d(S-O) / 100 p m)^{7,41}}+0,7
$$

gdje je $n(\mathrm{~S}-\mathrm{O})$ red veze $\mathrm{S}-\mathrm{O}$, a $d(\mathrm{~S}-\mathrm{O})$ duljine veze $\mathrm{S}-\mathrm{O}$. Primjenom jedn. (1) na opisane primjere struktura sumporne kiseline i njezinih aniona dobivaju se sljedeći rezultati. Veze S-O u sulfatnom ionu su izrazito parcijalnog dvostrukog karaktera jer se nalaze točno između jednostruke i dvostruke veze (red veze $n(\mathrm{~S}-\mathrm{O})$ iznosi od 1,5 do 1,6). Protoniranjem iona nastaje hidrogensulfatni ion u kojem su veze bitno različite: sulfatne veze se ponešto skraćuju $(n(\mathrm{~S}-\mathrm{O})$ iznosi od 1,6 do 1,7), a veza $\mathrm{S}-\mathrm{O}(\mathrm{H})$ se znatno produljuje i postaje bliža jednostrukoj vezi $(n(\mathrm{~S}-\mathrm{O})=1,3)$. Daljnjim protoniranjem u sumpornu kiselinu dvije sulfatne veze nastavljaju se skraćivati $(n(\mathrm{~S}-\mathrm{O})=1,8)$, a druge dvije veze slabog su parcijalno dvostrukog karaktera $(n(\mathrm{~S}-\mathrm{O})=1,3)$.

$U$ prirodi sulfati nastaju oksidacijom sulfita s kisikom. ${ }^{34}$ Sulfati se javljaju u hidrotermalnim izvorima. ${ }^{35}$ Najvažniji minerali sulfata su barit $\left(\mathrm{BaSO}_{4}\right)$, epsomit $\left(\mathrm{MgSO}_{4} \cdot 7 \mathrm{H}_{2} \mathrm{O}\right)$ i gips $\left(\mathrm{CaSO}_{4} \cdot 2 \mathrm{H}_{2} \mathrm{O}\right) .{ }^{36}$ Dio $\mathrm{SO}_{2}$ se $\mathrm{u}$ atmosferi raznim fotokemijskim reakcijama oksidira u sulfate ${ }^{37}$ i sumpornu kiselinu. ${ }^{25}$ Sulfat se pojavljuje i u sastavu vulkanskih plinova. ${ }^{35}$

Sulfat je važan anion koji ima brojne biosintetske i farmakološke funkcije te je sudionik mnogih fizioloških procesa. ${ }^{34}$ Primjerice, sulfoniranje je važan korak u biotransformaciji i detoksikaciji brojnih ksenobiotika (uključujući i analgetike, protuupalna sredstva i adrenergične stimulanse/blokatore), steroida, kateholamina i žučnih kiselina. ${ }^{34,38}$ Taj proces odvija se u citosolu ili Golgijevu aparatu. ${ }^{39}$ Sintetaza 3'-fosfoadenozin-5'-fosfosulfata (PAPS) (PAPSS, EC 2.7.7.4 i 2.7.1.25) katalizira sintezu PAPS-a koji služi kao univerzalni donor sumpora sa sulfatnog aniona, a prijenos sulfonata $\left(-\mathrm{SO}_{3}{ }^{-}\right)$na hidroksilnu ili amino-skupinu kataliziraju enzimi sulfotransferaze (EC 2.8.2). ${ }^{34,38-40}$ PAPS se primjenjuje u biosintezi mnogih esencijalnih spojeva (kondroitin-sulfata, dermatan-sulfata, keratan-sulfata, cerebrozid-sulfata $\mathrm{i}$ dr..${ }^{41}$ Mozak sisavaca na isti način metabolizira anorganski sulfat u 3 '-fosfoadenozin- 5 '-fosfosulfat i preostale sulfonatne spojeve. ${ }^{42}$ Struktura koenzima PAPS ${ }^{43}$ prikazana je na slici 2 pomoću molekulske grafike ${ }^{11} \mathrm{i}$ modeliranjem atoma vodika. ${ }^{44}$

Mikrobi probavnog sustava imaju važnu ulogu u metabolizmu kako organskih tako i anorganskih spojeva sumpora. ${ }^{45}$ Najviše ispitivani mikroorganizmi uključeni u metabolizam sumpora u debelom crijevu su bakterije koje reduciraju sulfate (BRS)..$^{45}$ Danas se zna za dvadesetak podvrsta BRS-a, na primjer za Desulfovibrio, Desulfomonas, Desulfotomaculum, Desulfolobus, Desulfobacter, Desulfoco-

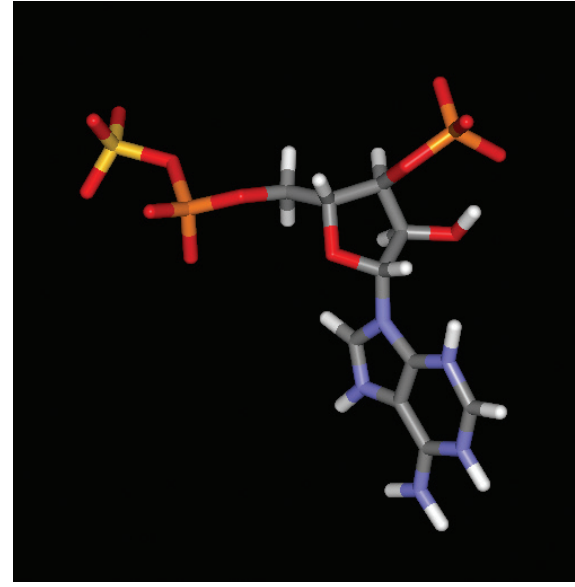

Slika 2 - Prikaz strukture koenzima PAPS

Fig. 2 - Representation of the structure of the PAPS coenzyme

cus, Desulfosarcina. Sulfat se u organizam unosi hranom ili nastaje oksidacijom aminokiselina koje sadrže sumpor, cisteina i metionina sadržanih u hrani te se može smatrati i endogenom sumporovom vrstom u ljudskom organizmu. ${ }^{34}$ Preporučeni dnevni unos sulfata za zdravu odraslu osobu je od 0,2 do 1,5 $\mathrm{g} \mathrm{d}^{-1}$, a za trudnice oko 1,7 $\mathrm{g} \mathrm{d}^{-1} \cdot{ }^{46} \mathrm{Na}$ kon unosa sulfat se apsorbira u krv, gdje se njegova razina odražava na oko $0,3-0,5 \mathrm{mmol}^{-1}$, što ga čini četvrtim najzastupljenijim anionom u ljudskoj plazmi. ${ }^{34,46,47}$ Istu koncentraciju ima u izvanstaničnoj tekućini, dok je koncentracija u staničnoj tekućini po prilici dvaput veća. Valja istaknuti da se sulfatni ioni i drugi anorganski anioni koji sadrže sumpor pojavljuju u ljudskom organizmu u obliku soli s metalnim kationima poput $\mathrm{Na}^{+}, \mathrm{K}^{+}, \mathrm{Ca}^{2+}{ }_{\mathrm{i}} \mathrm{Mg}^{2+}$. Suvišak sulfata u krvi brzo se izlučuje urinom, a manji dio se eliminira putem žuči i gušterače. ${ }^{48}$ Dnevno se izluči od 0,20 do 0,25 milimola sulfata po kilogramu tjelesne težine. Sulfat je jedan od najmanje toksičnih aniona. Smrtonosna doza kalijeva i cinkova sulfata iznosi $750 \mathrm{mg} \mathrm{kg}^{-1}$, a magnezijeva sulfata $200 \mathrm{mg} \mathrm{kg}^{-1}$. 46,48 Kada se konzumiraju u visokim koncentracijama, magnezijeve i natrijeve soli dovode do proljeva i dehidracije. Magnezijev sulfat (gorka sol) služi u medicini kao laksativ, a primjenjuje se i kao komponenta soli za kupke. ${ }^{49,50}$ Natrijev sulfat (Glauberova sol) isto se tako rabi kao laksativ. ${ }^{51}$ Za etil-sulfat, metabolit etanola u ljudskom organizmu, pak se drži da je potencijalni biomarker kod akutnog unosa alkohola. ${ }^{52}$

Potrebno je istaknuti da se cijeli niz endogenih anorganskih sumporovih vrsta u ljudskom organizmu poput primjerice sumporova dioksida i sulfita $\mathrm{SO}_{3}{ }^{2-}$, sumporovodika $\mathrm{H}_{2} \mathrm{~S}$, tiocianata $\mathrm{SCN}^{-}$i hipotiocianata $\mathrm{OSCN}^{-}$enzimskim reakcijama izravno ili neizravno prevodi u sulfat. ${ }^{53-63}$

\subsection{Tiosulfatni anion, endogeni antidot za cianid}

Tiosumporna kiselina (CAS registarski broj: 13686-287, relativna molekulska masa 114,14 ), kemijske formule $\mathrm{H}_{2} \mathrm{~S}_{2} \mathrm{O}_{3}$, nestabilna je kiselina koja se razlaže ubrzo nakon nastajanja. ${ }^{64}$ Može opstati samo na niskim temperaturama kao bezbojna uljasta tekućina. ${ }^{65}$ Disocijacijom molekule tiosumporne kiseline u prvom stupnju nastaje hidrogen- 
tiosulfatni anion $\left(\mathrm{HS}_{2} \mathrm{O}_{3}^{-}\right)$, a u drugom stupnju tiosulfatni anion $\left(\mathrm{S}_{2} \mathrm{O}_{3}{ }^{2-}\right)$ :

$$
\begin{aligned}
& \mathrm{H}_{2} \mathrm{~S}_{2} \mathrm{O}_{3}(\mathrm{aq})+\mathrm{H}_{2} \mathrm{O}(\mathrm{l}) \leftrightharpoons \mathrm{HS}_{2} \mathrm{O}_{3}{ }^{-}(\mathrm{aq})+\mathrm{H}_{3} \mathrm{O}^{+}(\mathrm{aq}), \\
& \mathrm{HS}_{2} \mathrm{O}_{3}{ }^{-}(\mathrm{aq})+\mathrm{H}_{2} \mathrm{O}(\mathrm{l}) \leftrightharpoons \mathrm{S}_{2} \mathrm{O}_{3}{ }^{2-}(\mathrm{aq})+\mathrm{H}_{3} \mathrm{O}^{+}(\mathrm{aq}) .
\end{aligned}
$$

Vrijednosti $\mathrm{pK}$ tiosumporne kiseline su $\mathrm{p} K_{\mathrm{a} 1}=0,6$ i $\mathrm{pK}_{\mathrm{a} 2}=1,74$. Kod $\mathrm{pH}=7,4(\mathrm{pH}$ krvi) prisutan je gotovo samo $\mathrm{S}_{2} \mathrm{O}_{3}{ }^{2-}$ ion (više od 99,999\%), $\mathrm{HS}_{2} \mathrm{O}_{3}{ }^{-}$je u tragovima $\left(2 \cdot 10^{-6}\right)$, a udjel $\mathrm{H}_{2} \mathrm{~S}_{2} \mathrm{O}_{3}$ je nezamjetan $\left(3 \cdot 10^{-11}\right)$. Kod nižeg $\mathrm{pH}=6,9$ ( $\mathrm{pH}$ mišićnih stanica) dominantna vrsta je također $\mathrm{S}_{2} \mathrm{O}_{3}{ }^{2-}$ (više od 99,999 \%), u tragovima je $\mathrm{HS}_{2} \mathrm{O}_{3}{ }^{-}$ $\left(7 \cdot 10^{-6}\right)$, a udjel kiseline $\mathrm{H}_{2} \mathrm{~S}_{2} \mathrm{O}_{3}$ je isto tako zanemariv $\left(3 \cdot 10^{-10}\right)$.

Tiosumporna kiselina i hidrogentiosulfatni anion nemaju potpuno poznatu molekulsku strukturu. ${ }^{66}$ Ramanovom spektroskopijom utvrđeno je da je atom vodika vezan za tiosumpor $\mathrm{u}$ hidrogentiosulfatnom anionu $\left(\mathrm{HS}_{-} \mathrm{SO}_{3}^{-}\right) \mathrm{u} \mathrm{kru-}$ tom $\mathrm{NH}_{4} \mathrm{HS}_{2} \mathrm{O}_{3} \cdot{ }^{67,68}$ Struktura tiosulfatnog aniona dobro je poznata iz kristalnih struktura tiosulfata: ustanovljeno je da je centralni sumporov atom u tiosulfatima tetraedarski koordiniran. ${ }^{29,65,69}$ Anion se može vezati na metalne katione atomima kisika ili atomom tio sumpora ${ }^{29,65}$ Veze S-S u anionu nešto su kraće od jednostruke veze sumpor-sumpor, a veze $\mathrm{S}-\mathrm{O}$ su parcijalnog dvostrukog karaktera kao u sulfatnom anionu. ${ }^{29,65,69}$ Tako su primjerice duljine veza S-S i S-O 201 pm i 147 pm u magnezijevu tiosulfatu heksahidratu, u kojem anion nije koordiniran na metal. ${ }^{65} \mathrm{U}$ kompleksnom spoju olova(III) formule $\mathrm{Pb}_{3}\left(\mathrm{~S}_{2} \mathrm{O}_{4}\right)_{2}\left(\mathrm{CH}_{3} \mathrm{COO}\right)_{2}$ tiosulfat je vezan na metalne katione atomima kisika, a duljine veza S-S i S-O iznose 205 pm i od 146 do 148 pm. ${ }^{70}$ Vezni kutevi S-S-O i O-S-O u tiosulfatu bliski su idealnom tetraedarskom kutu od 109, $5^{\circ} .29,65,69,70$

Red veze S-S može se izračunati iz duljine veze S-S prema formuli koja je slična jedn. (1), a može se izvesti iz statističkih analiza i strukturnih podataka za sumporove okso-spojeve koje je objavio Steudel: ${ }^{71,72}$

$$
n(S-S)=\frac{117,35}{(d(S-S) / 100 p m)^{7,26}}+0,4
$$

gdje je $n(\mathrm{~S}-\mathrm{S})$ red veze $\mathrm{S}-\mathrm{S}$, a $d(\mathrm{~S}-\mathrm{S})$ duljine veze $\mathrm{S}-\mathrm{S}$. Duljina jednostruke veze je 206 pm u ( $S_{8}$ molekula), a dvostruke $181 \mathrm{pm}\left(\mathrm{S}_{2}\right.$ molekula). ${ }^{72}$ Kada se jedn. (1) i (2) primjene na opisane strukture koje sadrže tiosulfatni anion, uočava se da su veze $\mathrm{S}-\mathrm{O}$ vrlo slične analognim vezama u sulfatnom ionu $(n(\mathrm{~S}-\mathrm{O})=1,6)$, a veza $\mathrm{S}-\mathrm{S}$ je gotovo jednostruka ( $(\mathrm{S}-\mathrm{S})$ iznosi od 1,0 do 1,1$)$. Drugim riječima, postoje dva bitno različita atoma sumpora. Stupanj oksidacije središnjeg atoma sumpora u tiosulfatu je VI, a drugog sumporova atoma $-11 .{ }^{64}$

Tiosulfatni ion relativno je postojan u neutralnoj i bazičnoj otopini, dok u kiseloj otopini dolazi do disproporcioniranja tiosulfatnog iona uslijed djelovanja oksonijeva iona $\left(\mathrm{H}_{3} \mathrm{O}^{+}\right):{ }^{64}$

$$
\begin{gathered}
\mathrm{S}_{2} \mathrm{O}_{3}{ }^{2-}(\mathrm{aq})+2 \mathrm{H}_{3} \mathrm{O}^{+}(\mathrm{aq}) \leftrightharpoons \mathrm{H}_{2} \mathrm{~S}_{2} \mathrm{O}_{3}(\mathrm{aq})+\mathrm{H}_{2} \mathrm{O}(\mathrm{l}), \\
\mathrm{H}_{2} \mathrm{~S}_{2} \mathrm{O}_{3}(\mathrm{aq}) \leftrightharpoons \mathrm{SO}_{2}(\mathrm{~g})+\mathrm{S}^{0}(\mathrm{~s})+\mathrm{H}_{2} \mathrm{O}(\mathrm{l}) .
\end{gathered}
$$

Poznati su geogeni izvori tiosulfata: hidrotermalni izvori, vrlo rijetki minerali kao što je sidpietersit i razni proizvodi oksidacije kao rezultat dugog djelovanja bakterija. ${ }^{73-75}$ Najvažnija sol slabe i nepostojane tiosumporne kiseline je natrijev tiosulfat pentahidrat, $\mathrm{Na}_{2} \mathrm{~S}_{2} \mathrm{O}_{3} \cdot 5 \mathrm{H}_{2} \mathrm{O} .{ }^{76,77}$ Natrijev tiosulfat slabo je toksičan proizvod kemijske industrije, ima dugu povijest medicinske uporabe, a također je poznat kao konzervans u hrani (npr. kuhinjska sol, alkoholna pića). ${ }^{78,79}$ Nekada se više upotrebljavao kao antidot pri trovanju bizmutom, arsenom, olovom i živom. $\mathrm{Na}_{2} \mathrm{~S}_{2} \mathrm{O}_{3}$ kao važan antioksidans pokazuje antiinflamatorni, antineuroinflamatorni, neuroprotektivni te antikalcifikacijski učinak $\mathrm{s}$ vazodilatacijskim učinkom. Kao antioksidans sudjeluje u sintezi sumporovodika enzimskim reakcijama transsulfuracije te reduciranog koenzima glutationa. $U$ medicini se rabi u liječenju gljivičnih infekcija kože, osteoartritisa, pri intoksikaciji jodom, cianidom, cisplatinom ili kalcijevim hipokloritom, kod oštećenja kože ili očiju srebrovim(I) nitratom ili kalijevim permanganatom. ${ }^{79-81}$ Natrijev tiosulfat također je učinkovit u liječenju nekih rijetkih medicinskih poremećaja kao što su kalcifilaksije (okoštavanje arterija s tkivnom ishemijom i nekrozom) i nekih kožnih oboljenja. ${ }^{78,82}$ Ustanovljeno je da tiosulfat ima pozitivno djelovanje i na hiperoksaluriju (povećano izlučivanje oksalata) i očuvanje bubrežne funkcije. ${ }^{83}$ Endogeni tiosulfat može poslužiti u razne dijagnostičke svrhe, no prije analize nužna je kvalitetna priprema uzorka. ${ }^{84} \mathrm{U}$ serumu zdrave osobe pronađen je u mikromolarnim koncentracijama $\left(6,6 \pm 2,4\right.$ umol I $\left.^{-1}\right){ }^{84}$ Konstantna proizvodnja endogenog tiosulfata procjenjuje

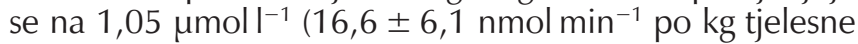
mase), a ista vrijednost se primjenjuje za daljnje izračune. ${ }^{84}$ Također je izmjerena koncentracija tiosulfata u 24-satnom urinu zdrave osobe, koja se kreće u rasponu od 0,3 do 10,2 $\mathrm{mmol}$ dok je srednja vrijednost 2,1 $\mu$ mol..$^{85}$ Veće vrijednosti tiosulfata u 24-satnom urinu pronađene su u pacijentima s transplantatom bubrega i mogu pomoći za predviđanje preživljavanja. ${ }^{85}$ Jin i sur. ${ }^{86}$ su pokazali da je mjerenje tiosulfata od velikog značaja za postavljanje dijagnoze trovanja sumporovodikom što se upotrebljava u forenzici. Ustanovljeno je kako različitim uzrocima smrti (trovanje sumporovodikom i hipotermija) odgovaraju bitno različite koncentracije tiosulfata u serumu.

Tiosulfat u ljudskom tijelu nastaje enzimskom ili neenzimskom oksidacijom ili redukcijom sumpornih spojeva, ali i enzimskim djelovanjem bakterija. ${ }^{6}$ Bakterije prisutne u lumenu debelog crijeva proizvode sulfide redukcijom sulfata i sulfita unesenih hranom, fermentacijom aminokiselina koje sadrže sumpor te metabolizmom mukopolisaharida koji u svojem sastavu imaju sulfate. ${ }^{87}$ Sisavci se štite od toksičnih učinaka sulfida tako što ih u mitohondrijima stanica sluznice debelog crijeva oksidiraju u tiosulfat. Sulfidi se u mitohondrijima oksidiraju u tiosulfate složenim nizom enzimskih reakcija. Sulfid-kinon-oksidoreduktaza (SQOR, EC 1.8.5.4) oksidira $\mathrm{H}_{2} \mathrm{~S}$ do elementarnog sumpora, a istodobno se reducira cistein disulfid oksidoreduktaze tako da se persulfidna skupina -SSH oblikuje na jednom od cisteina. ${ }^{61}$ Oslobođeni elektroni ulaze u respiracijski lanac posredstvom molekula kinona i na kraju se prenose na kisik $\mathrm{O}_{2}$ pomoću citokrom-c-oksidaze (COX, EC 1.9.3.1). Sumpor-dioksigenaza (SDO, EC 1.13.11.18) u mitohondrijskom matriksu oksidira persulfide - $\mathrm{SSH}$ u sulfite, uz sudjelovanje molekulskog kisika i vode. Završnu 


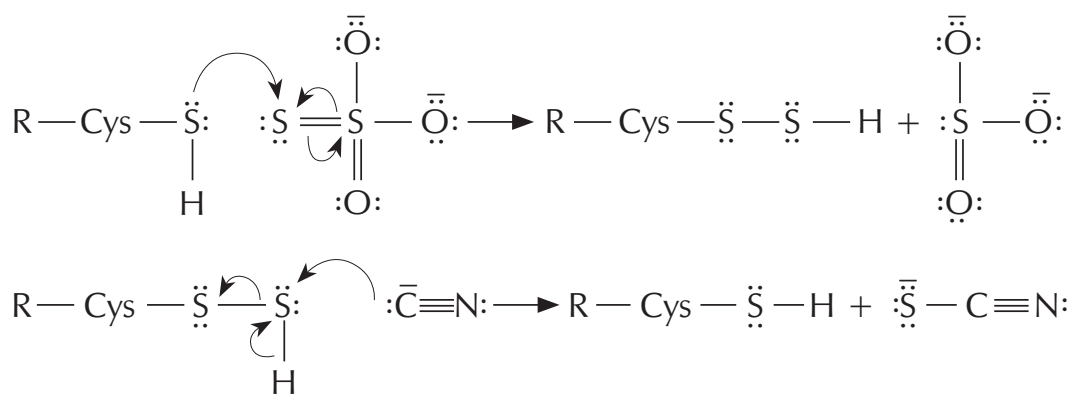

Slika 3 - Prikaz pretpostavljenog mehanizma detoksikacije cianida rodanazom

Fig. 3 - Representation of the assumed mechanism for rhodanese-catalysed cyanide detoxification

reakciju katalizira tiosulfat-tiol-sumpor-transferaza (TST, EC 2.8.1.3), koja proizvodi tiosulfat prevodeći drugu persulfidnu skupinu aktiviranog enzima SQOR u sulfit. Stvorenim tiosulfatom crijevne bakterije se koriste namjesto kisikom za respiraciju. ${ }^{87}$ Rodovi crijevnih bakterija koji ponajviše reduciraju tiosulfat su Salmonella, Proteus, Edwardsiella i Citrobacter.

Fiziološke uloge endogenog tiosulfata u ljudskom tijelu još uvijek nisu u dovoljnoj mjeri istražene. ${ }^{88}$ Zna se da ima detoksikacijsku, antioksidativnu i zaštitnu ulogu, tj. uklanja cianid, reducira glutation i druge spojeve, a višak sumporovodika, sulfida i sulfita se oksidira u neotrovan tiosulfat. Kao posrednik bitan je međuprodukt u metabolizmu sumpornih spojeva. Uostalom, služi kao izvor sumpora za proizvodnju sumporovodika. Može se vjerovati da će se u bliskoj budućnosti pronaći i druge fiziološke funkcije tiosulfata u ljudskom tijelu. Temeljna je fiziološka funkcija multifunkcionalnog enzima rodanaze (Rhod) detoksikacija izlučivanjem cianida iz organizma. ${ }^{89}$ Ta funkcija je posebno uočena u sisavaca, gdje se vrlo toksičan cianid pretvara u manje toksičan tiocianat i sulfit (slika 3):

$$
\mathrm{S}_{2} \mathrm{O}_{3}{ }^{2-}(\mathrm{aq})+\mathrm{CN}^{-}(\mathrm{aq}) \leftrightharpoons \mathrm{SCN}^{-}(\mathrm{aq})+\mathrm{SO}_{3}{ }^{2-}(\mathrm{aq}) .
$$

Atom sumpora se prenosi s tiosulfata na aktivno mjesto cisteinske skupine - $\mathrm{SH}$ rodanaze, pri čemu nastaje persulfidna skupina $-\mathrm{SSH}$, koja potom reagira s cianidom. ${ }^{61} \mathrm{U}$ povratnoj reakciji, sulfit reagira sa skupinom -SSH dajući tiocianat. Potom se tiocianat izlučuje putem bubrega iz tijela. ${ }^{89}$

\subsection{Anion $\mu$-disulfido-bis(trioksosulfat)(2-) (tetrationat), nusproizvod patogenog stanja u crijevima}

Divodikov $\mu$-disulfido-bis(trioksosulfat)(2-) ili tetrationska kiselina (CAS broj: 15536-54-6, relativna molekulska masa $226,25)$ je oksokiselina sumpora formule $\mathrm{H}_{2} \mathrm{~S}_{4} \mathrm{O}_{6}$. Spada u skupinu politionskih kiselina $\mathrm{HO}_{3} \mathrm{~S}-(\mathrm{S})_{n}-\mathrm{SO}_{3} \mathrm{H}$ koje se javljaju kao bezbojne, uljaste tekućine stabilne na niskim temperaturama. ${ }^{65}$ Disocijacijom kiseline $\mathrm{H}_{2} \mathrm{~S}_{4} \mathrm{O}_{6}$ u dva stupnja nastaje konačni produkt anion $\mu$-disulfido-bis(trioksosulfat) (2-) (tetrationat) $\mathrm{S}_{4} \mathrm{O}_{6}{ }^{2-}$ :

$$
\begin{gathered}
\mathrm{H}_{2} \mathrm{~S}_{4} \mathrm{O}_{6}(\mathrm{aq})+\mathrm{H}_{2} \mathrm{O}(\mathrm{l}) \leftrightharpoons \mathrm{HS}_{4} \mathrm{O}_{6}{ }^{-}(\mathrm{aq})+\mathrm{H}_{3} \mathrm{O}^{+}(\mathrm{aq}), \\
\mathrm{HS}_{4} \mathrm{O}_{6}{ }^{-}(\mathrm{aq})+\mathrm{H}_{2} \mathrm{O}(\mathrm{l}) \leftrightharpoons \mathrm{S}_{4} \mathrm{O}_{6}{ }^{2-}(\mathrm{aq})+\mathrm{H}_{3} \mathrm{O}^{+}(\mathrm{aq}) .
\end{gathered}
$$

Točne vrijednosti $p K_{a 1}$ i $p K_{a 2}$ nisu poznate. Pretpostavlja se da je vrijednost $p K_{\mathrm{a} 1}$ oko 2, ${ }^{90}$ a $p K_{\mathrm{a} 2}$ oko nule. ${ }^{91}$ Dakle, radi se o jakoj kiselini koja u vodenoj otopini postoji isključivo u obliku aniona $\mathrm{S}_{4} \mathrm{O}_{6}{ }^{2-}$, dok su udjeli aniona $\mathrm{HS}_{4} \mathrm{O}_{6}{ }^{-}$i slobodne kiseline $\mathrm{H}_{2} \mathrm{~S}_{4} \mathrm{O}_{6}$ zanemarivi kod sobne temperature kao i kod $37^{\circ} \mathrm{C}$.

Slobodne politionske kiseline nisu stabilne na sobnoj temperaturi, već egzistiraju samo pri niskim temperaturama u nevodenim medijima. ${ }^{92}$ Daju stabilne soli politionate. Nisu poznate strukture slobodnih kiselina. Strukturno su okarakterizarani različiti metalni $\mu$-disulfido-bis(trioksosulfati)(2-). Anion $\mathrm{S}_{4} \mathrm{O}_{6}{ }^{2-}$ može se vezati na metalni kation na različite načine. Primjerice, u kristalnoj strukturi kalijeve soli $\left(\mathrm{K}_{2} \mathrm{~S}_{4} \mathrm{O}_{6}\right)^{93}$ jedan je anion koordiniran na katione svim kisikovim atomima, a drugi je koordiniran na katione još i središnjim atomima sumpora. U kristalnoj strukturi bis(1,10-fenantrolin- $\left.N, N^{\prime}\right)$ bakrova(II) $\mu$-disulfido-bis(trioksosulfata)(2-) pentahidrata ${ }^{94}$ anion pak nije koordiniran na metal. lonski anion $\mathrm{S}_{4} \mathrm{O}_{6}{ }^{2-}$ je građen od dvije tiosulfatne tetraedarske jedinke spojene vezom S-S. Prilično je stabilne strukture s obzirom na utjecaj okoline, što se vidi po manjim varijacijama u duljinama veza i valentnim kutevima: u navedenim strukturama središnja veza $\mathrm{S}-\mathrm{S}$ je duljine oko 200 pm, čime je malo kraća od jednostruke veze sumpor-sumpor u $\mathrm{S}_{8}$ molekuli $(206 \mathrm{pm}),{ }^{72}$ a susjedne veze $\mathrm{S}-\mathrm{S}$ nešto su dulje. Veze $\mathrm{S}-\mathrm{O}$ nešto su kraće od analognih u sulfatnom anionu. Uvrštavanjem tih podataka u jedn. (1) i (2) dobivaju se zanimljivi rezultati: uočava se naizmjenično skraćivanje i produljivanje veza. Veze S-O imaju izraženiji parcijalni dvostruki karakter od analognih veza u sulfatnom ionu $(n(\mathrm{~S}-\mathrm{O})$ nalazi se u rasponu $1,7-1,8)$, rubne veze $S-S$ su duge jednostruke veze, a središnja veza $S-S$ ima malen parcijalni dvostruki karakter $(n(S-S)$ iznosi $1,1-1,2)$. Unutarnji vezni kutevi S-S-S u tiosulfatu su manji, a vanjski kutevi S-S-O i O-S-O veći su od idealnog tetraedarskog kuta. Ovisno o interakciji s okolinom tetraedri mogu zauzimati različite međusobne položaje, pa vrijednosti torzijskog kuta S-S-S-S mogu varirati oko $90^{\circ} \mathrm{ili}-90^{\circ}$. Struktura $\mathrm{S}_{4} \mathrm{O}_{6}{ }^{2-}$ aniona ${ }^{94}$ prikazana 


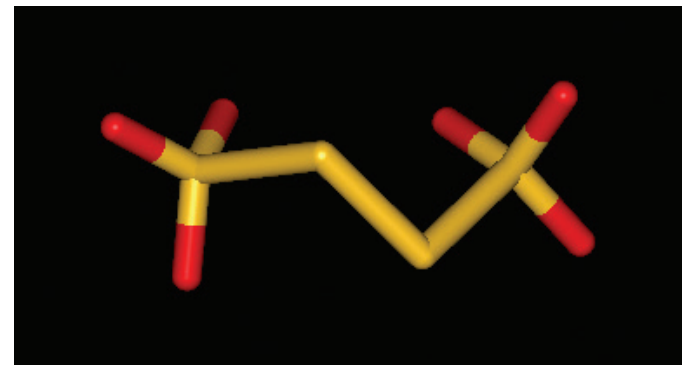

Slika 4 - Prikaz strukture aniona $\mathrm{S}_{4} \mathrm{O}_{6}{ }^{2-}$

Fig. 4 - Representation of the structure of anion $\mathrm{S}_{4} \mathrm{O}_{6}{ }^{2-}$

je na slici 4 s pomoću molekulske grafike. ${ }^{11}$ Nisu poznate strukture slobodne kiseline $\mathrm{H}_{2} \mathrm{~S}_{4} \mathrm{O}_{6}$ i aniona $\mathrm{HS}_{4} \mathrm{O}_{6}{ }^{-}$.

$\mathrm{U}$ prirodi se $\mathrm{S}_{4} \mathrm{O}_{6}{ }^{2-}$ nalazi u malim količinama kao međuprodukt redoks reakcija spojeva sumpora, posebice oksidacije tiosulfata: ${ }^{95-100}$ geogen (vulkani, termalni izvori), biogen (morski sedimenti, bakterije) i antropogen (izluživanje zlata iz ruda, oksidacija sumpornih gnojiva u tlu).

Anion $\mathrm{S}_{4} \mathrm{O}_{6}{ }^{2-}$ uglavnom se ne javlja u normalnim fiziološkim uvjetima, već u patogenom stanju, tijekom upale crijeva. ${ }^{101}$ Crijevne bakterije stalno proizvode $\mathrm{H}_{2} \mathrm{~S}$ i oslobađaju ga u lumen crijeva, gdje se taj toksikant nakuplja tek u mikromolarnim koncentracijama jer se dijelom apsorbira fecesom, a dijelom ga mukozne stanice crijeva oksidiraju u netoksičan tiosulfat pomoću enzima sulfid-kinon-oksidoreduktaze (SQOR, EC 1.8.5.4) uz prisustvo sulfita. ${ }^{102}$ Tijekom upale crijeva, koja može biti uzrokovana i izrazitim porastom koncentracije sumporovodika, ${ }^{102}$ aktivirani neutrofili u lumenu crijeva proizvode razne reaktivne kisikove vrste (radikale superoksid ${ }^{\cdot} \mathrm{O}_{2}{ }^{-}$, hidroksil ${ }^{\circ} \mathrm{OH}$ i dušikov monoksid $\mathrm{NO}$ i oksidanse hipoklorit $\mathrm{OCl}^{-}$i vodikov peroksid $\mathrm{H}_{2} \mathrm{O}_{2}$ ) nizom enzimskih i neenzimskih reakcija. ${ }^{101,103} \mathrm{Te}$ vrste reagiraju s tiosulfatom čime nastaje $\mathrm{S}_{4} \mathrm{O}_{6}{ }^{2-}$. Međutim, Salmonella typhimurium i druge patogene enterobakterije uvelike se razmnožavaju u crijevu jer se u anaerobnim uvjetima umjesto molekulskim kisikom koriste za staničnu respiraciju upravo anionom $\mathrm{S}_{4} \mathrm{O}_{6}{ }^{2-}$, koji će reducirati u tiosulfat i dalje u sulfit i sumporovodik. ${ }^{104,105}$ Novija istraživanja ${ }^{101,104}$ pokazuju da te patogene enterobakterije izazivaju upalu crijeva ispuštajući faktore virulencije, što uzrokuje stvaranje aniona $\mathrm{S}_{4} \mathrm{O}_{6}{ }^{2-}$. Također se utvrdilo postojanje humanog selenoenzima tioredoksin-reduktaze 1 (TR1, EC 1.8.1.9) koja oksidira $\mathrm{S}_{4} \mathrm{O}_{6}{ }^{2-}$ u tiosulfat. ${ }^{104}$ Pretpostavlja se da bi se dodacima prehrani koji sadrže selen povećala koncentracija enzima TR1 u lumenu crijeva, čime bi se spriječilo štetno djelovanje spomenutih patogena.

\section{Ostali endogeni okso-spojevi sumpora}

\subsection{Sumporov dioksid, nova signalna molekula}

Sumporov dioksid (CAS registracijski broj: 7446-09-5, relativna molekulska masa 64,06 ) je spoj formule $\mathrm{SO}_{2}$. Veza sumpor-kisik u molekuli sumporova dioksida je parcijalnog dvostrukog karaktera duljine 143 pm $(n(S-O)=1,8$ prema jedn. (1), a kut $\mathrm{O}=\mathrm{S}=\mathrm{O}$ iznosi $120^{\circ}{ }^{26,65}$ Plin je bez boje, specifičnog neugodnog, bockava mirisa i kiselkastog okusa, korozivan, ne gori niti podržava gorenje. ${ }^{65,106} \mathrm{Vrlo}$ je jako redukcijsko sredstvo te se kao takav oksidira do sulfata. Lako je topljiv u vodi (1 volumna jedinica vode otapa oko 40 volumnih jedinica plina pri $20{ }^{\circ} \mathrm{C}$ ) i takvom reakcijom nastaje kisela otopina, poznata i kao $\mathrm{SO}_{2}$-vo$\mathrm{da},{ }^{107}$ koja djeluje korozivno. ${ }^{65} \mathrm{U}$ malim koncentracijama $\left(0,04 \%\right.$ volumnog udjela u zraku, a 0,3 \% u vodi) $\mathrm{SO}_{2}$ je toksičan te uzrokuje upalu dišnih organa, otežano disanje, zamućenje rožnice i žarenje u želucu. ${ }^{65}$ Sumporov dioksid je najzastupljeniji spoj sumpora antropogenog porijekla u atmosferi s volumnim udjelom oko $2 \cdot 10^{-10} \%$. $^{108} \mathrm{U}$ atmosferi reagira $\mathrm{s}$ radikalima ${ }^{\circ} \mathrm{OH}$ stvarajući sumpornu kiselinu i sumporov trioksid te se stoga vijek $\mathrm{SO}_{2} \mathrm{u}$ atmosferi procjenuje na samo oko jedan tjedan. ${ }^{109} \mathrm{U}$ prirodi nastaje iz antropogenih, geogenih, biogenih i fotokemijskih izvora. ${ }^{108-110}$ Glavni antropogeni izvori su proizvodnja energije, industrija, termoelektrane, promet, spaljivanje otpada. Geogeni izvori uključuju vulkane i termalne izvore, dok biogeni obuhvaćaju hlapljive organske spojeve bogate sumporom koji odlaze $\mathrm{u}$ atmosferu gdje se iz njih proizvodi $\mathrm{SO}_{2}$. Fotokemijskim reakcijama u atmosferi biogeni spojevi sumpora mogu se oksidirati u sumporov dioksid. U prehrambenoj industriji se upotrebljava kao aditiv u plinovitom stanju ili kao kisela vodena otopina koja zbog disocijacije sadrži $\mathrm{H}_{3} \mathrm{O}^{+}, \mathrm{HSO}_{3}{ }^{-} \mathrm{i} \mathrm{SO}_{3}{ }^{2-}$ ione te u obliku soli sumporaste kiseline, sulfita. ${ }^{111}$

Endogeni sumporov dioksid se stvara u tijelu na dva različita načina, neenzimskom i enzimskom biosintezom. Enzimska proizvodnja sumporova dioksida odvija se putem razgradnje aminokiseline cistein (slika 5). ${ }^{112}$ L-cistein se oksidira pomoću cistein-dioksigenaze (CDO, EC 1.13.11.20) uz prisustvo vode i oksonijevih iona u $L$-cistein-sulfinat. ${ }^{113,114}$ Cistein-sulfinat-dekarboksilaza može dekarboksilirati L-cistein-sulfinat u hipotaurin, a taj se može djelovanjem hipotaurin-dehidrogenaze (EC 1.8.1.3) oksidirati u taurin. ${ }^{53,54}$ Glutamat-oksaloacetat-transaminaza (GOT, EC 2.6.1.1) s PLP kofaktorom (piridoksal-5'-fosfat) i $\alpha$-ketoglutaratom uklanja amino-skupinu s $L$-cistein-sulfinata dajući $\beta$-sulfinilpiruvat. ${ }^{112,113}$ In vivo $\beta$-sulfinilpiruvat se uz sudjelovanje oksonijevih iona spontano raspada u piruvat i sumporov dioksid. Nastali $\mathrm{SO}_{2}$ brzo reagira s vodom te nastaje sulfit koji sulfit-oksidaza (SO, EC 1.8.3.1) prevodi u sulfat. ${ }^{53,54}$

Neenzimska sinteza sumporova dioksida odvija se u neutrofilnim granulocitima kao posljedica oksidacijskog stresa koji uzrokuje pretvorbu $\mathrm{H}_{2} \mathrm{~S}$ u $\mathrm{SO}_{3}{ }^{2-}$. ${ }^{112,113}$

Sumporov dioksid vrlo je čest zagađivač zraka, a njegovo štetno djelovanje zahvaća i mnoge organe. Uz toksične učinke $\mathrm{SO}_{2}$ u sisavcima su pronađeni i zaštitni učinci. Najnovija istraživanja ${ }^{115,116}$ pokazala su da $\mathrm{SO}_{2}$ ima vrlo širok spektar djelovanja poput antioksidativnog, antihipertenzivnog, antiinflamatornog, antiaterogenog djelovanja te da ima važnu ulogu u regulaciji funkcije kardiovaskularnog sustava, kalcijeva ionskog kanala i metabolizma lipida. Ta otkrića sugeriraju da je endogeni $\mathrm{SO}_{2}$ nova signalna molekula ili plinoviti glasnik koji ima važnu ulogu u kontroli fiziološke i patofiziološke funkcije u ljudskom tijelu. 

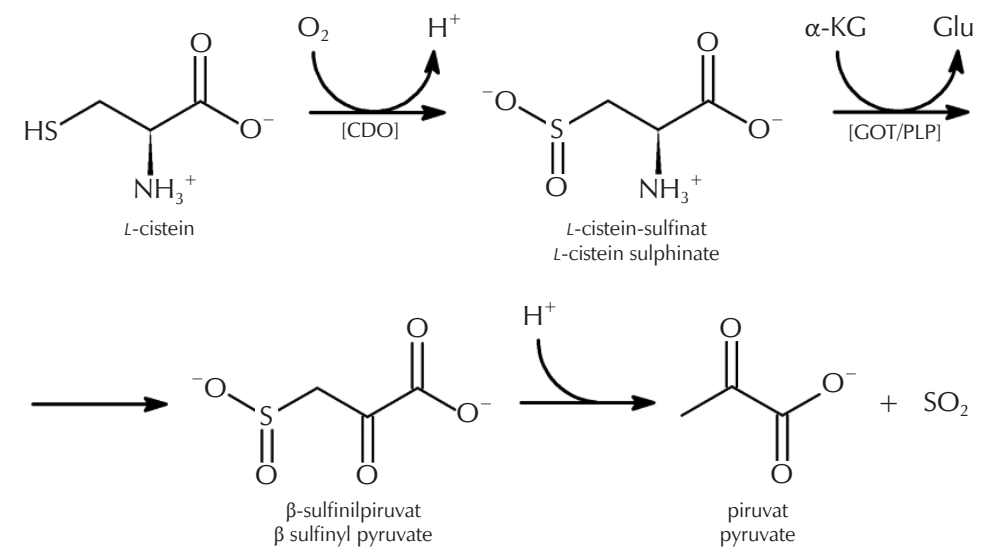

Slika 5 - Enzimski biosintetski put sumporova dioksida u ljudskom tijelu Fig. 5 - Enzymatic biosynthesis pathway for sulfur dioxide in the human
body

\subsection{Produkti reakcije sumporova dioksida i vode u ljudskom organizmu: hidrogensulfitni, sulfonatni, sulfitni i disulfitni anion}

Sumporasta kiselina ili divodikov trioksosulfat $\mathrm{H}_{2} \mathrm{SO}_{3}$ (CAS registarski broj: 7782-99-2, relativna molekulska masa $82,08)$ je oksokiselina sumpora koja teoretski može nastati reakcijom sumporova dioksida i vode, međutim, njezino postojanje na Zemlji nikada nije dokazano zbog termodinamičke nestabilnosti u plinskoj fazi na uobičajenim temperaturama (poluvrijeme života na $27^{\circ} \mathrm{C}$ je samo jedan dan) i u vodenom mediju (vodeni medij katalizira brzi raspad $\mathrm{H}_{2} \mathrm{SO}_{3}$ na $\mathrm{SO}_{2} \mathrm{i}_{2} \mathrm{O}$ ). ${ }^{117}$ Pretpostavlja se da slobodna $\mathrm{H}_{2} \mathrm{SO}_{3}$ postoji u atmosferama nekih svemirskih objekata kao što su Jupiterovi sateliti Europa i lja, gdje se nalaze idealni uvjeti za nastanak i stabilnost sumporaste kiseline. Drugim riječima, $\mathrm{H}_{2} \mathrm{SO}_{3}$ ne postoji niti u biološkim sustavima, barem ne u količinama koje se mogu zapaziti. ${ }^{69}$ Otapanjem $\mathrm{SO}_{2} \mathrm{u}$ vodi nastaje hidrogensulfitni $\left(\mathrm{HOSO}_{2}{ }^{-}\right)$odnosno sulfonatni $\left(\mathrm{HSO}_{3}{ }^{-}\right)$anion ili disulfitni anion $\left(\mathrm{S}_{2} \mathrm{O}_{5}{ }^{2-}\right){ }^{26,118}$ Disocijacijom hidrogensulfitnog iona nastaje sulfitni anion $\mathrm{SO}_{3}{ }^{2-}$ :

$$
\begin{aligned}
& \mathrm{SO}_{2}(\mathrm{~g})+2 \mathrm{H}_{2} \mathrm{O}(\mathrm{l}) \leftrightharpoons \mathrm{HOSO}_{2}{ }^{-}(\mathrm{aq})+\mathrm{H}_{3} \mathrm{O}^{+}(\mathrm{aq}) \\
& \mathrm{HOSO}_{2}{ }^{-}(\mathrm{aq})+\mathrm{H}_{2} \mathrm{O}(\mathrm{l}) \leftrightharpoons \mathrm{SO}_{3}{ }^{2-}(\mathrm{aq})+\mathrm{H}_{3} \mathrm{O}^{+}(\mathrm{aq}) .
\end{aligned}
$$

Vrijednosti $\mathrm{pK}$ prve i druge reakcije iznose 1,85 odnosno $7,2 .{ }^{26} \mathrm{Kod} \mathrm{pH}=7,4(\mathrm{pH} \mathrm{krvi})$ dominantne vrste su $\mathrm{SO}_{3}{ }^{2-}$

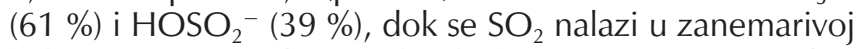
količini $\left(10^{-6}\right)$. Kod nižeg fiziološkog $\mathrm{pH}=6,9$ raspodjela dominantnih vrsta bitno je drugačija $\left(\mathrm{SO}_{3}{ }^{2-} \approx 33 \%\right.$; $\mathrm{HOSO}_{2}{ }^{-} \approx 67 \%$ ), a udjel $\mathrm{SO}_{2}$ nije više zanemariv $(0,06 \%)$. Može se očekivati da je pri tjelesnoj temperaturi $\left(37^{\circ} \mathrm{C}\right)$ disocijacija hidrogensulfita pojačana. Međutim hidrogensulfit tautomerizira u sulfonatni anion $\mathrm{HSO}_{3}{ }^{-}$(vodik vezan na sumporov atom):

$$
\mathrm{HOSO}_{2}^{-}(\mathrm{aq}) \leftrightharpoons \mathrm{HSO}_{3}^{-}(\mathrm{aq})
$$

s konstantom ravnoteže tautomerizacije $K_{\mathrm{t}}=1 / 4,9\left(25^{\circ} \mathrm{C} \mathrm{i}\right.$ ionska jakost 1,0 mol dm $\left.{ }^{-3}\right),{ }^{119}$ što znači da oko $17 \%$ hidrogensulfita tautomerizira u sulfonat. Udjel tautomeriziranog hidrogensulfita povećava se porastom temperature. ${ }^{120}$ Nisu poznata istraživanja koja bi se bavila sulfonatnim anionom u ljudskom tijelu ili općenito u živim bićima. Razlog tome leži u činjenici da se $\mathrm{HSO}_{3}{ }^{-}$anioni ne mogu detektirati za male ionske jakosti (manje od 0,2 mol dm ${ }^{-3}$ ) ${ }^{69}$ kao što je krvna plazma (ionska jakost 0,16 $\mathrm{mol} \mathrm{dm}^{-3}$ ). ${ }^{121}$

Hidrogensulfit $\mathrm{HOSO}_{2}{ }^{-}$dimerizira u manjoj mjeri u disulfit $\mathrm{S}_{2} \mathrm{O}_{5}{ }^{2-}$, ovisno o ionskoj jakosti otopine: ${ }^{118,122}$

$$
2 \mathrm{HOSO}_{2}{ }^{-}(\mathrm{aq}) \leftrightharpoons \mathrm{S}_{2} \mathrm{O}_{5}{ }^{2-}(\mathrm{aq})+\mathrm{H}_{2} \mathrm{O}(\mathrm{l})
$$

Bourne i sur. ${ }^{122}$ su pokazali da konstanta ravnoteže dimerizacije $K_{d}$ raste gotovo linearno s ionskom jakošću. Na osnovi njihovih podataka procjenjuje se da je $K_{\mathrm{d}}=0,13 \mathrm{~mol} \mathrm{dm}^{-3}$ za ionsku jakost krvne plazme. Nisu poznata istraživanja o ulozi endogenog disulfita u ljudskom tijelu.

Sufitni anion $\mathrm{u}$ ionskim sulfitima ima oblik trigonske piramide s veznim kutevima $\mathrm{O}-\mathrm{S}-\mathrm{O}$ manjim od idealnog tetraedarskog zbog postojanja slobodnog elektronskog para na atomu sumpora. ${ }^{65,120,123,124}$ Duljine veza S-O iznose, primjerice, 151 - 153 pm u kristalnoj strukturi $\mathrm{CaSO}_{3} \cdot 0.5 \mathrm{H}_{2} \mathrm{O},{ }^{124}$ a $152 \mathrm{pm} \mathrm{u}$ kristalnoj strukturi sulfatno-sulfitnog minerala $\mathrm{Ca}_{3} \mathrm{Si}(\mathrm{OH})_{6}\left(\mathrm{SO}_{4}\right)\left(\mathrm{SO}_{3}\right) \cdot 11 \mathrm{H}_{2} \mathrm{O} .{ }^{123}$ Sulfonatni anion ima oblik deformiranog tetraedra sa sljedećim parametrima: kratke veze S-O duljine 144 pm i veza S-H duljine 138 pm, dok su kutevi O-S-O veći, a O-S-H manji od 109,50. ${ }^{120}$ Međutim, hidrogensulfitni ion ima oblik trigonske piramide kao sulfitni ion, s atomom vodika na jednom od kisikovih atoma u dva moguća položaja (anti- i sin-položaji s obzirom na atom sumpora). ${ }^{125} \mathrm{Nalazi}$ se kao monodentatni ligand u kristalnoj strukturi organometalnog iridijeva(I) spoja, s anti-položajem atoma vodika. ${ }^{126}$ Veze S-O u hidrogensulfitnom ionu kraće su kada je kisik vezan na iridij (152 pm) ili vodik (151 pm), a treća 
<smiles>O=S(=O)([O-])[O-]</smiles>

sulfonat sulphonate

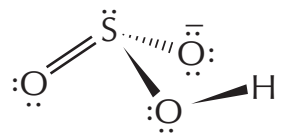

anti-hidrogensulfit anti-hydrogen-sulphite

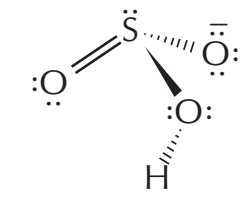

sin-hidrogensulfit sin-hydrogen-sulphite

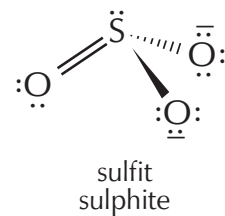

sulphite

Slika 6 - Lewisov prikaz sulfonatnog, anti- i sin-izomera hidrogensulfitnog i sulfitnog aniona

Fig. 6 - Lewis representation of the sulfonate, anti- and syn-hydrosulfite isomers and sulphite anions

veza je dulja (155 pm). Kutevi O-S-O su manji od idealnog tetraedarskog. Strukturne formule aniona sulfonata, hidrogensulfita i sulfita prikazane su jednom rezonantnom strukturom na slici 6 .

Disulfitni anion ima složenu strukturu koja se sastoji od skupina $\mathrm{SO}_{3}$ i $\mathrm{SO}_{2}$ spojenih vezom $\mathrm{S}-\mathrm{S}$. U kristalnoj strukturi natrijeva disulfita ${ }^{127}$ anion $\mathrm{S}_{2} \mathrm{O}_{5}{ }^{2-}$ nema ravninu simetriju. Duljina veze S-S iznosi 222 pm, a duljine veza S-O su od 146 do 147 pm u skupini SO i od 149 do 150 pm u skupini $\mathrm{SO}_{2}$. U strukturnom smislu skupina $\mathrm{SO}_{3}$ disulfita vrlo je slična analognoj skupini $\mathrm{SO}_{3}$ tiosulfata. Skupina $\mathrm{SO}_{2}$ je bitno različita zbog postojanja slobodnog elektronskog para na atomu sumpora, zbog čega su vezni kutevi S-S-O i O-S-O manji od analognih u skupini $\mathrm{SO}_{3}$. Struktura disulfitnog aniona ${ }^{122}$ prikazana je na slici 7 s pomoću molekulske grafike. ${ }^{11}$

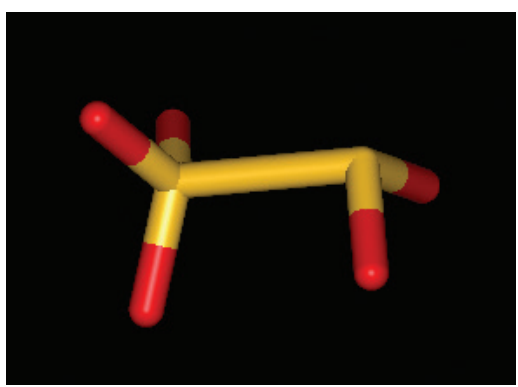

Slika 7 - Prikaz strukture disulfitnog aniona

Fig. 7 - Representation of the structure of disulphite anion

Izračunom vrijednosti redova veza $n(\mathrm{~S}-\mathrm{O})$ prema jedn. (1) moguće je objasniti razlike među anionima koji su nastali otapanjem $\mathrm{SO}_{2}$ u vodi. Red veze u sulfitnom anionu je 1,4, što je manje nego u sulfatnom ionu. $U$ hidrogensulfitnom ionu dvije veze imaju $n(\mathrm{~S}-\mathrm{O})=1,4$, a veza $\mathrm{S}-\mathrm{O}(\mathrm{H})$ je nešto dulja $(n(\mathrm{~S}-\mathrm{O})=1,3)$. Međutim, u sulfonatnom ionu sve veze $\mathrm{S}-\mathrm{O}$ znatno se skraćuju $(n(\mathrm{~S}-\mathrm{O})=1,7)$ uslijed protonacije atoma sumpora. $\mathrm{U}$ disulfitnom ionu razlike $\mathrm{u}$ redu veze između skupina $\mathrm{SO}_{3}$ i $\mathrm{SO}_{2}$ nisu značajne: za $\mathrm{SO}_{3}$ skupinu $n(\mathrm{~S}-\mathrm{O})$ iznosi 1,6 , a za $\mathrm{SO}_{2}$ skupinu 1,5, što znači da su obje skupine bliske sulfatnom ionu.

Sumporov dioksid u prirodi reagira s vodom, čime nastaju kisele otopine sulfitnog aniona koji s metalnim kationima gradi soli, sulfite. Takve soli se obično oksidiraju u sulfa- te ili reduciraju u spojeve s nižim oksidacijskim stanjima sumpora, a reakcije su moguće $u$ anorganskim materijalima i u živim organizmima. Sulfiti rijetko ulaze u sastav minerala. ${ }^{123} \mathrm{U}$ vrlo malim količinama nalaze se $u$ fosilnim gorivima kao rezultat djelovanja bakterija. ${ }^{75} \mathrm{U}$ ljudski organizam sulfiti se ponajprije unose preko aditiva iz hrane ili pića. Takvi spojevi su, primjerice, natrijev i kalijev hidrogensulfit, natrijev i kalijev disulfit te natrijev sulfit, koji se upotrebljavaju kao konzervansi jer sprječavaju neenzimsko tamnjenje hrane (Maillardove reakcije), enzimske reakcije i djelovanje mikroba. ${ }^{128-131}$ Maksimalne dozvoljene količine sulfita propisane su za svaku vrstu hrane i pića. ${ }^{128}$ Sulfiti se unose i dodatcima prehrani, lijekovima i kozmetičkim sredstvima. ${ }^{130,131}$ Kada je ukupna količina unesenog sumporova dioksida i njegovih derivata (soli) viša od maksimalnog dozvoljenog dnevnog unosa $\left(0-0,7 \mathrm{mg} \mathrm{kg}^{-1}\right)$, moguća su različita oboljenja poput suženja bronha kod oboljelih od astme, kontaktni dermatitis, sniženi krvni tlak i dr. ${ }^{128,130,131}$

Bazalna koncentracija sulfita u krvnoj plazmi odrasle osobe varira uslijed prehrane i načina života u značajnom rasponu $\left(0,1-10 \mu \mathrm{mol} \mathrm{dm}^{-3}\right){ }^{129}$ Potječe od egzogenog i endogenog sulfita. Endogeni uključuje sulfit u hrani, piću, dodatcima prehrani, lijekovima i kozmetičkim sredstvima te bilo kakvu intoksikaciju sulfitom. Neke crijevne bakterije proizvode sulfitni anion kao međuprodukt u proizvodnji sumporovodika iz sulfatnog aniona i organskih spojeva sumpora, ${ }^{132}$ no nije poznato doprinose li značajno te reakcije ukupnoj količini endogenog sulfita. Zna se da endogeni sulfit nastaje uglavnom enzimskom i rjeđe neenzimskom redukcijom spojeva s višim oksidacijskim stanjem sumpora poput tiosulfata i sulfata, a razgrađuje se obrnutim putem reakcijama oksidacije. ${ }^{55-61}$ Slika 8 prikazuje glavne biosintetske i biorazgradljive puteve sulfita s poznatim enzimskim mehanizmima reakcija. Tiosulfat je supstrat u biosintetskim putevima 1 i 2, a reakcije oksidacije kataliziraju se enzimima iz skupine sumportransferaza: put 1 katalizira Rhod (rodanaza, poznata i kao tiosulfat-cianid-sumportransferaza, EC 2.8.1.1), a put 2 enzim TST (tiosulfat-tiol-sumportransferaza, EC 2.8.1.3). Sumpor tiosulfata u oksidacijskom stanju (-II) prenosi se na donor sumpora, na cianid, čime nastaje tiocianat (put 1), ili na glutationski anion $\left(\mathrm{GS}^{-}\right)$koji prelazi u glutation-persulfidni anion $\left(\mathrm{GSS}^{-}\right.$, struktura na dnu slike 8). Biosintetski put 3 počinje $\mathrm{GSS}^{-}$anionom, koji se oksidira molekulskim kisikom, pri čemu nastaju $\mathrm{GS}^{-}$i sulfit, uz katalitičko djelovanje enzima SDO (sumpor-dioksigenaza, EC 1.13.11.18). Biorazgradljivi putevi 4 i 5 uključuju oksidaciju sulfita u sulfat (put 4) i tiosulfat (put 
5). Nastali elektroni i oksonijevi ioni služe u reakcijama respiracijskog lanca u mitohondrijima. Enzim SO (sulfit-oksidaza, EC 1.8.3.1) katalizira put 4 uz sudjelovanje vode, a enzim SQOR (sulfid-kinon-oksidoreduktaza, EC 1.8.5.4) put 5 uz sudjelovanje hidrogensulfida. Svi enzimi na slici 8 kataliziraju i povratne reakcije.

Sulfiti u dijagnostici služe za utvrđivanje poremećaja metabolizma sulfita. Oralni podražajni testovi i algerijski testovi na sulfite primjenjuju se za utvrđivanje intolerancije i alergije na sulfite. ${ }^{133}$ Sulfitni test urina ${ }^{134}$ služi za utvrđivanje rijetkih nasljednih metaboličkih bolesti - deficijencije enzima SO (sulfit-oksidaze) ${ }^{135}$ i deficijencije njegova molibdenskog kofaktora (kompleksni spoj piranopterin-ditiolata i molibdena). ${ }^{136}$ Posljedice genetičkih mutacija jesu pogreške u primarnoj strukturi enzima SO te pogreške u enzimima koji sintetiziraju molibdenski kofaktor. Krajnji ishod je nefunkcionalni enzim i posljedično nakupljanje sulfita i tiosulfata, koji nastaje redukcijom sulfita u biosintetskim putevima 1 i 2 da se djelomično kompenzira nakupljanje sulfata (slika 7). Sulfit u visokim koncentracijama inhibira mnoge enzime, posebno u mozgu. ${ }^{137}$

Sulfitni anion, osim što predstavlja bitnu kariku u metabolizmu sumpornih spojeva, vjerojatno ima i druge fiziološke uloge. Mistuhashi $i$ sur. ${ }^{138}$ tvrde da neutrofili oslobađanju sulfitni anion koji potom služi za oksidaciju bakterijskih proteina i time je važan obrambeni čimbenik protiv infekcija.

\section{Zaključak}

Endogeni okso-spojevi sumpora nastaju enzimskim ili neenzimskim biosintetskim putevima u stanicama ili izvanstaničnom prostoru ljudskog organizma. Riječ je o ionskim spojevima, solima najzastupljenijih metala u organizmu $\left(\mathrm{Na}^{+}, \mathrm{K}^{+}, \mathrm{Ca}^{2+} \mathrm{i} \mathrm{Mg}^{2+}\right)$ i oksokiselina sumpora (sumporna, tiosumporna i sumporasta kiselina te $\mu$-disulfido-bis(trioksosulfat)(2-)) i sumporovu dioksidu. Ukupnoj količini spojeva doprinose i endogena bakterijska flora, unos u organizam (hrana i dodatci prehrani, medicinski preparati i kozmetička sredstva), utjecaj okoliša i intoksikacija. Od zasebne važnosti su anioni sulfat, tiosulfat, $\mu$-disulfido-bis(trioksosulfat)(2-), sulfit, sulfonat, hidrogensulfit i disulfit, koji se kao $\mathrm{SO}_{2}$ mogu smatrati endogenim neradikalnim oksovrstama sumpora u ljudskom tijelu. Većinom su jednostavne strukture (sulfat, tiosulfat, sumporov dioksid, sulfit i sulfonat), a neke vrste su složenije (disulfit i $\mu$-disulfido-bis(trioksosulfat)(2-)). Koncentracije im ovise o $\mathrm{pH}$ tjelesne tekućine i o konstanti reakcije kojom nastaju.

Atom sumpora u sulfatnom anionu je u najvišem oksidacijskom stanju (VI) i nema slobodnog elektronskog para, što uzrokuje kemijsku intertnost aniona. Sulfat se nalazi u tjelesnim tekućinama u milimolarnim koncentracijama kao redoviti sastojak elektrolita. Izvor je sumpora u enzimskoj i neenzimskoj biosintezi brojnih anorganskih i organskih spojeva.

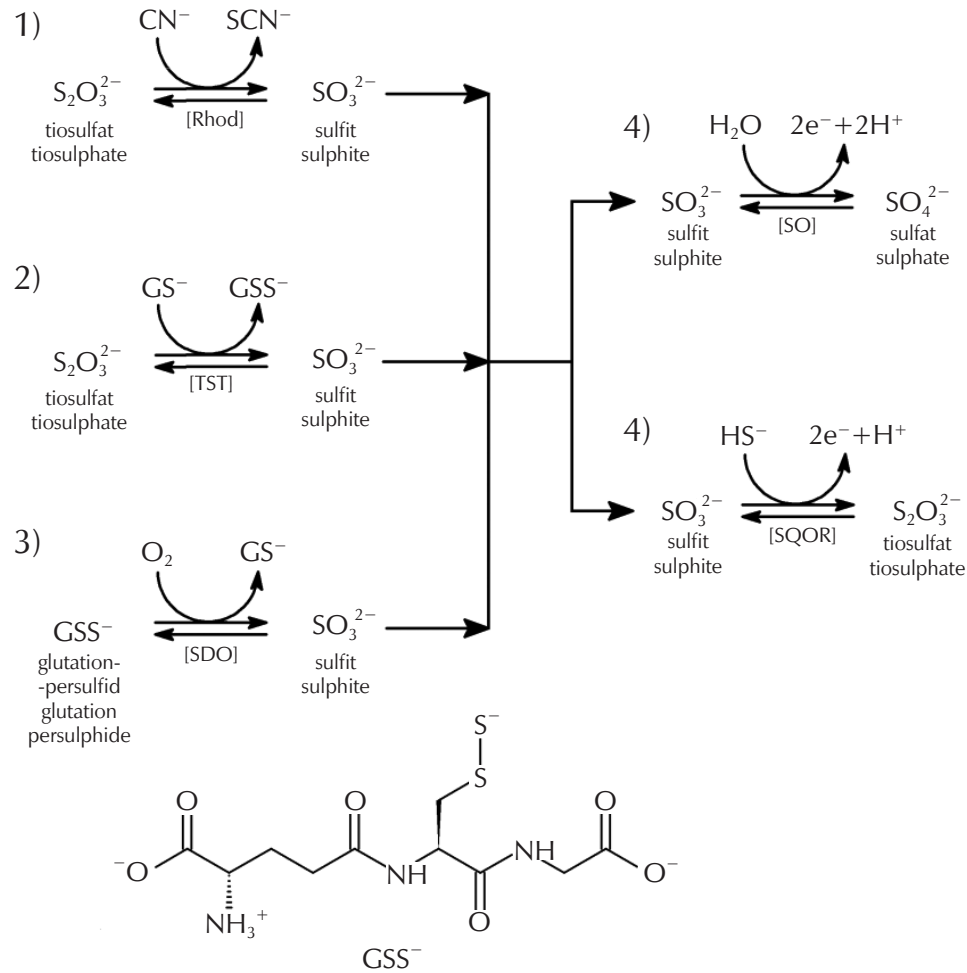

Slika 8 - Enzimski biosintetski i biorazgradljivi putevi sulfita u ljudskom tijelu: sinteza iz tiosulfata $(1,2)$ i glutation-persulfida (3), te razgradnja u sulfat (4) i tiosulfat (5)

Fig. 8 - Enzymatic biosynthesis and biodegradation pathways for sulfite in the human body: synthesis from thiosulfate $(1,2)$ and glutathione persulfide (3), and degradation into sulfate (4) and thiosulfate (5) 
Atomi sumpora u različitim oksidacijskim stanjima (-II) i (VI) međusobno su povezani u tiosulfatu, a tiosumpor ima tri slobodna elektronska para, stoga je anion reaktivniji od sulfata. U ljudskom organizmu nalazi se u mikromolarnim koncentracijama. Ima brojne zaštitne funkcije i važan je međuprodukt u metabolizmu sumpornih spojeva. Spajanjem dviju tiosulfatnih jedinki vezom sumpor-sumpor nastaje anion $\mu$-disulfido-bis(trioksosulfat)(2-) s oksidacijskim stanjima sumpora (0) i (VI). Stvara se u milimolarnim koncentracijama tijekom upale crijeva. Nepoželjni je metabolit čije postojanje nije poznato u normalnim fiziološkim uvjetima.

Molekula sumporova dioksida strukturno je jednostavna: atom sumpora u oksidacijskom stanju (IV) vezan je na dva atoma kisika s vezama izrazito parcijalno dvostrukog karaktera i ima slobodan elektronski par. Reaktivna je i u reakciji s vodom pri fiziološkim vrijednostima $\mathrm{pH}$ daje anione sulfit, hidrogensulfit i sulfonat u mikromolarnim i bisulfit $u$ pikomolarnim koncentracijama. $U$ novije vrijeme dobiva status signalne molekule u nanomolarnim koncentracijama u procesima kontrole fiziološke i patofiziološke funkcije u ljudskom tijelu. Sulfonat i disulfit mogu se smatrati izvorom sulfita i hidrogensulfita, dvaju prilično reaktivnih aniona (atom sumpora ima slobodni elektronski par), koji se nalaze u mikromolarnim koncentracijama u tjelesnim tekućinama. Oba aniona važni su međuprodukti u metabolizmu sumpornih spojeva.

Opisane endogene sumporove vrste zadivljuju širokom lepezom uloga, kao što su fiziološke, patološke, metaboličke, detoksikacijske, kurativne, forenzičke i druge. Treba očekivati da će u bliskoj budućnosti biti otkrivene nove uloge, razjašnjene na molekulskoj razini.

\section{ZAHVALA}

Autori se posebno zahvaljuju profesorici dr. sc. Dubravki Matković-Čalogović sa Zavoda za opću i anorgansku kemiju Prirodoslovno-matematičkog fakulteta u Zagrebu, za pretraživanje struktura hidrogensulfita u kristalografskim bazama.

\section{Popis kratica i simbola List of abbreviations and symbols}

$$
\begin{array}{ll}
\alpha-K G & -\alpha \text {-ketoglutarat } \\
& -\alpha \text {-ketoglutarate } \\
\text { BRS } & - \text { bakterije koje reduciraju sulfate } \\
& - \text { sulphate-reducing bacteria }
\end{array}
$$

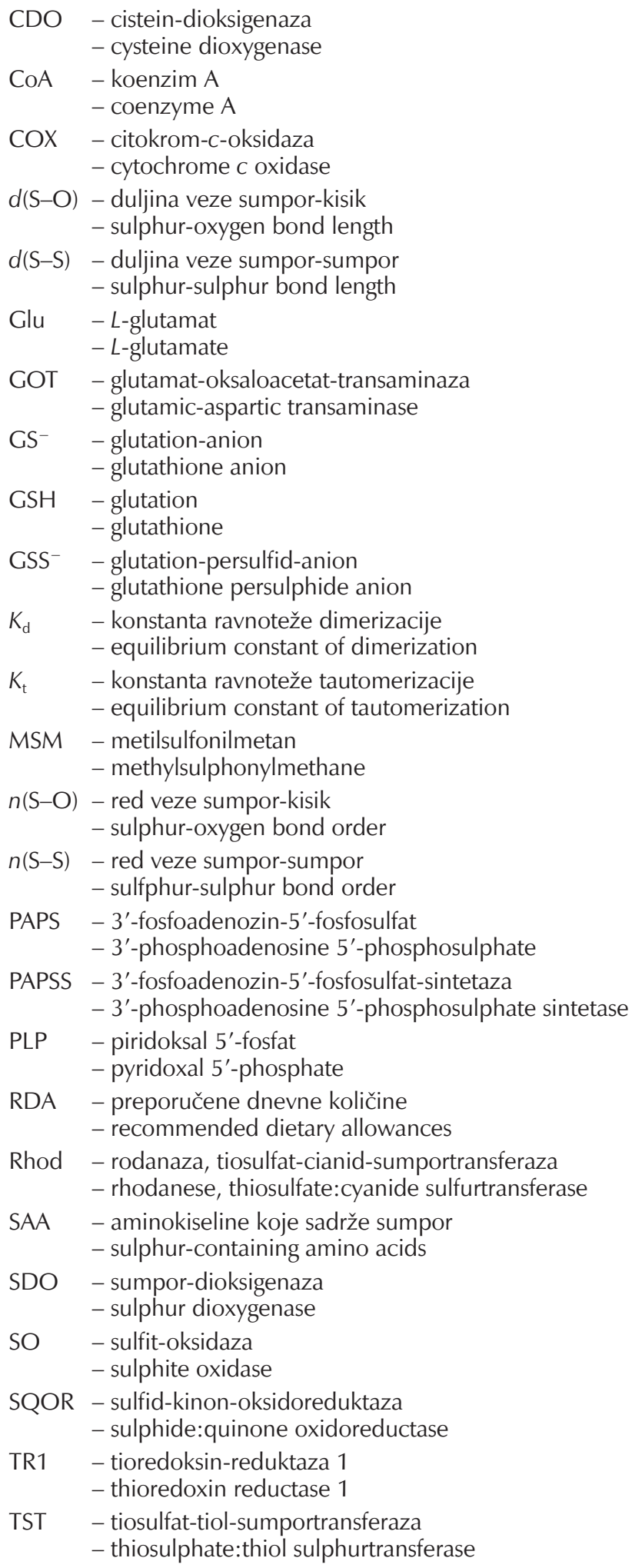




\section{Literatura \\ References}

1. URL: http://www.enciklopedija.hr/natuknica.aspx?ID=58761 (24. 7. 2016.)

2. D. E. Canfield, Biogeochemistry of sulfur isotopes, Rev. Mineral. Geochem. 43 (2001) 607-636, doi: https://doi. org/10.2138/gsrmg.43.1.607.

3. J. Emsley, Vodič kroz elemente, Izvori, Zagreb 2005.

4. Lj. Kovačević, I. Žugaj, Kemijski elementi, Media Sci, Zagreb 1996.

5. URL: http://www.pse.pbf.hr/hrvatski/elementi/s/index.htmI\#OPCENITO (12. 11. 2016.)

6. H. L. Ehrlich, D. K. Newman, Geomicrobiology $5^{\text {th }}$ edition, CRC Press, Boca Raton, FL, 2009.

7. I. Filipović, S. Lipanović, Opća i anorganska kemija II dio, Školska knjiga, Zagreb 1991.

8. Z. Svečnjak, Željezo i bor nužni za rast i razvoj biljaka, Green Garden 10 (67) (2010) 18.

9. R. Steudel, B. Eckert, Solid sulfur allotropes, Top. Curr. Chem. 230 (2003) 1-79, doi: https://doi.org/10.1007/b12110.

10. S. J. Rettig, J. Trotter, Refinement of the structure of orthorhombic sulfur, $\alpha-S_{8}$, Acta Cryst. C 43 (1987) 2260-2262, doi: https://doi.org/10.1107/S0108270187088152.

11. ViewerLite 4.2, Accelrys, Inc., San Diego, CA, 2001.

12. N. Ozbek, A. Baysal, A new approach for the determination of sulphur in food samples by high-resolution continuum source flame atomic absorption spectrometer, Food Chem. 168 (2015) 460-463, doi: https://doi.org/10.1016/j.foodchem.2014.07.093.

13. M. E. Nimni, B. Han, F. Cordoba, Are we getting enough sulfur in our diet?, Nutr. Metab. (Lond.) 4 (2007) 24 (12 str.), doi: https://doi.org/10.1186/1743-7075-4-24.

14. Lj. Ǐsgum Vorgić, Medicinska biokemija, Medicinska naklada, Zagreb, 2006.

15. C. R. Robbins, Chemical and physical behavior of human hair, Springer, Berlin, 2012.

16. Abeceda vitamina i minerala, Dušević \& Kršovnik, Rijeka 2007.

17. URL: http://www.healthy.net/scr/article.aspx?ID $=2066$ (12. 11. 2016.)

18. Dossiê: os minerais na alimentação, Food Ingredients Brasil 4 (2008) 48-65.

19. D. G. Searcy, S. H. Lee, Sulfur reduction by human erythrocytes, J. Exp. Zool. 282 (1998) 310-322, doi: https://doi. org/10.1002/(SICI)1097-010X(19981015)282:3<310::AIDJEZ4 > 3.0.CO;2-P.

20. B. Momčilović, Značenje proteina, vitamina i mikroelemenata u cijeljenju rane, Medix 9 (51) (2003) 66-70.

21. Y. Ingenbleek, Hyperhomocysteinemia is a biomarker of sulfur-deficiency in human morbidities, Open Clin. Chem. J. 2 (2009) 49-60, doi: https://doi.org/10.2174/1874241600 902010049.

22. P. H. Itin, A. Sarasin, M. R. Pittelkow, Trichothiodystrophy: Update on the sulfur-deficient brittle hair syndrome, J. Am. Acad. Dermatol. 44 (2001) 891-920, doi: https://doi. org/10.1067/mjd.2001.114294.

23. M. M. Fall, E. H. M. Niang, C. D. Niang, B. Niang, A. K. Toure, B. Diatta, Serious burn by sulfuric acid: case report of particular therapeutic strategy in a non-specialized ICU at Hôpital Principal de Dakar (HPD) Sénégal, Open J. Emerg. Med. 4 (2016) 62-68, doi: https://doi.org/10.4236/ ojem.2016.43009
24. URL: http://www.enciklopedija.hr/natuknica.aspx$? \mathrm{id}=58765(15.11 .2016$.

25. J. Li, M. Jang, Kinetic study of esterification of sulfuric acid with alcohols in aerosol bulk phase, Atmos. Chem. Phys. Discuss. 13 (2013) 23217-23250, doi: https://doi.org/10.5194/ acpd-13-23217-2013.

26. W. M. Haynes (ur.), CRC Handbook of Chemistry and Physics 95 ${ }^{\text {th }}$ Edition 2014-2015, CRC Press, Boca Raton, FL, 2014.

27. G. A. Tanner, Acid-Base Balance, u R. A. Rhoades, G. A. Tanner (ur.), Medical Physiology $2^{\text {nd }}$ edition, Lippincott Williams \& Wilkins, Philadelphia, PA, 1994, str. 426-477.

28. D. J. Aframian, T. Davidowitz, R. Benoliel, The distribution of oral mucosal $\mathrm{pH}$ values in healthy saliva secretors, Oral Dis. 12 (2006) 420-423, doi: https://doi.org/10.1111/j.16010825.2005.01217.x.

29. A. F. Wells, Structural Inorganic Chemistry $4^{\text {th }}$ edition, Oxford University Press, London, 1975, str. 570-604.

30. X. Liu, Y. Xing, K. Shao, G. Li, N. Xu, L. Ma, Synthesis and structure of a chiral copper(II) sulfate $\left(\mathrm{C}_{3} \mathrm{~N}_{2} \mathrm{H}_{4}\right)_{3} \mathrm{CuSO}_{4}$ from achiral materials, Z. Anorg. Allgem. Chem. 635 (2009) 2627-2630, doi: https://doi.org/10.1002/zaac.200900229.

31. T. J. Lukianova, V. Kinzhybalo, A. Pietraszko, Crystal structure of tris(piperidinium) hydrogen sulfate sulfate, Acta Cryst. E 71 (2015) 1444-1446, doi: https://doi.org/10.1107/ S2056989015020538.

32. E. Kemnitz, C. Werner, S. Trojanov, Reinvestigation of crystalline sulfuric acid and oxonium hydrogen sulfate, Acta Cryst. C 52 (1996) 2665-2668, doi: https://doi.org/10.1107/ S0108270196006749.

33. R. J. Gillespie, E. A. Robinson, The sulphur-oxygen bond in sulphuryl and thionyl compounds: correlation of stretching frequencies and force constants with bond lengths, bond angles, and bond orders, Can. J. Chem. 41 (1963) 2074-2085, doi: https://doi.org/10.1139/v63-299.

34. D. Markovich, Physiological roles and regulation of mammalian sulfate transporters, Physiol. Rev. 81 (2001) 1499-1533.

35. R. O. Rye, A review of the stable-isotope geochemistry of sulfate minerals in selected igneous environments and related hydrothermal systems, Chem. Geol. 215 (2005) 5-36, doi: https://doi.org/10.1016/j.chemgeo.2004.06.034.

36. Sulfate in drinking-water - background document for development of WHO guidelines for drinking-water quality, WHO/SDE/WSH/03.04/114, World Health Organization, Geneva, 2004.

37. J. L. Hand, B. A. Schichtel, W. C. Malm, M. L. Pitchford, Particulate sulfate ion concentration and $\mathrm{SO}_{2}$ emission trends in the United States from the early 1990s through 2010, Atmos. Chem. Phys. 12 (2012) 10353-10365, doi: https://doi. org/10.5194/acp-12-10353-2012.

38. N. Gamage, A. Barnett, N. Hempel, R. G. Duggleby, K. F. Windmill, J. L. Martin, M. E. McManus, Human sulfotransferases and their role in chemical metabolism, Toxicol. Sci. 90 (2006) 5-22, doi: https://doi.org/10.1093/toxsci/kfj061.

39. C. D. Klaassen, J. W. Boles, Sulfation and sulfotransferases 5: the importance of 3'-phosphoadenosine 5'-phosphosulfate (PAPS) in the regulation of sulfation, FASEB J. 11 (1997) 404-418.

40. K. V. Venkatachalam, Human 3'-phosphoadenosine 5'-phosphosulfate (PAPS) synthase: biochemistry, molecular biology and genetic deficiency, IUBMB Life 55 (2003) 1-11, doi: https://doi.org/10.1080/1521654031000072148.

41. Dietary reference intakes for water, potassium, sodium chloride, and sulfate, National Academies Press, Washington, DC, 2005 
42. A. S. Balasubramanian, B. K. Bachhawat, Sulfate metabolism in brain, Brain Res. 29 (1970) 341-360, doi: https://doi. org/10.1016/0006-8993(70)90165-4.

43. L. C. Pedersen, E. Petrotchenko, S. Shevtsov, M. Negishi, Crystal structure of the human estrogen sulfotransferase-PAPS complex, J. Biol. Chem. 277 (2002) 17928-17932, doi: https://doi.org/10.1074/jbc.M111651200.

44. ArgusLab 4.0.1, Planaria Software LLC, Lake Forest Park, WA, 2004.

45. F. Carbonero, A. C. Benefiel, A. H. Alizadeh-Ghamsari, H. R. Gaskins, Microbial pathways in colonic sulfur metabolism and links with health and disease, Front. Physiol. 3 (2012) 448 (11 str.), doi: https://doi.org/10.3389/fphys.2012.00448.

46. P. A. Dawson, A. Elliott, F. G. Bowling, Sulphate in pregnacy, Nutrients 7 (2015) 1594-1606, doi: https://doi.org/10.3390/ nu7031594.

47. A. Lutkić, A. Jurić, Biokemija 6. izdanje, Medicinska naklada, Zagreb, 2008.

48. URL: http://healthycanadians.gc.ca/publications/healthyliving-vie-saine/water-sulphate-sulfate-eau/index-eng.php (6. 11. 2016.)

49. URL: http://www.eurokor.hr/index.php/proizvoai/ kemijske-sirovine-i-proizvodi/89-magnezijev-sulfat (15. 11. 2016.)

50. URL: http://proleksis.lzmk.hr/23976/ (15. 11. 2016.)

51. URL: http://www.enciklopedija.hr/natuknica.aspx?ID=22204 (15. 11. 2016.)

52. F. M. Wurst, S. Dresen, J. P. Allen, G. Wiesbeck, M. Graf, W. Weinmann, Ethyl sulphate: a direct ethanol metabolite reflecting recent alcohol consumption, Addiction 101 (2006) 204-211, doi: https://doi.org/10.1111/j.13600443.2005.01245.x.

53. O. W. Griffith, Cysteinesulfinate metabolism: altered partitioning between transamination and decarboxylation following administration of $\beta$-methyleneaspartate, J. Biol. Chem. 258 (1983) 1591-1598.

54. M. H. Stipanuk, I. Ueki, Dealing with methionine/homocysteine sulfur: cysteine metabolism to taurine and inorganic sulfur, J. Inherit. Metab. Dis. 34 (2011) 17-32, doi: https:// doi.org/10.1007/s10545-009-9006-9.

55. A. Stein, S. M. Bailey, Redox biology of hydrogen sulfide: Implications for physiology, pathophysiology, and pharmacology, Redox Biol. 1 (2013) 32-39, doi: https://doi. org/10.1016/j.redox.2012.11.006.

56. B. Olas, Hydrogen sulfide in hemostasis: Friend or foe? Chem. Biol. Int. 217 (2014) 49-56, doi: https://doi.org/10.1016/j. cbi.2014.04.006.

57. G. K. Kolluru, X. Shen, S. C. Bir, C. G. Kevil, Hydrogen sulfide chemical biology: Pathophysiological roles and detection, Nitric Oxide 35 (2013) 5-20, doi: https://doi.org/10.1016/j. niox.2013.07.002

58. S. L. Melideo, M. R. Jackson, M. S. Jorns, Biosynthesis of a central intermediate in hydrogen sulfide metabolism by a novel human sulfurtransferase and its yeast ortholog, Biochemistry 22 (2014) 4739-2753, doi: https://doi.org/10.1021/ bi500650h.

59. C. Feng, G. Tollin, J. H. Enemark, Sulfite oxidizing enzymes, Biochim. Biophys. Acta 1774 (2007) 527-539, doi: https:// doi.org/10.1016/j.bbapap.2007.03.006.

60. K. Johnson-Winters, G. Tollin, J. H. Enemark, Elucidating the catalytic mechanism of sulfite oxidizing enzymes using structural, spectroscopic and kinetic analyses, Biochemistry 49 (2010) 7242-7254, doi: https://doi.org/10.1021/bi1008485.

61. T. M. Hildebrandt, M. K. Grieshaber, Three enzymatic ac- tivities catalyze the oxidation of sulfide to thiosulfate in mammalian and invertebrate mitochondria, FEBS J. 275 (2008) 3352-3361, doi: https://doi.org/10.1111/j.17424658.2008.06482.x

62. J. Kalmár, K. L. Woldegiorgis, B. Biri, M. T. Ashby, Mechanism of decomposition of the human defense factor hypothiocyanite near physiological pH, J. Am. Chem. Soc. 133 (2011) 19911-19921, doi: https://doi.org/10.1021/ja2083152.

63. R. Wang, Physiological implications of hydrogen sulfide: A whiff exploration that blossomed, Physiol. Rev. 92 (2012) 791-896, doi: https://doi.org/10.1152/physrev.00017.2011.

64. A. Prkić, Vježbe iz Analitičke kemije (interna recenzirana skripta), Kemijsko-tehnološki fakultet u Splitu, Zavod za analitičku kemiju, Split, 2014, str. 55.

65. A. F. Holleman, E. Wiberg, N. Wiberg, Inorganic Chemistry, Academic Press, San Diego, CA, 2001, str. 503-572.

66. K. Miaskiewicz, R. Steudel, The structure of thiosulfuric acid $\mathrm{H}_{2} \mathrm{~S}_{2} \mathrm{O}_{3}$ and its monoanion $\mathrm{HS}_{2} \mathrm{O}_{3}{ }^{-}$, Angew. Chem. Int. Ed. 31 (1992) 58-59, doi: https://doi.org/10.1002/ anie. 199200581

67. R. Steudel, A. H. Otto, Geometries, acidities, and dissociation reactions of the gaseous superacids $\mathrm{H}_{2} \mathrm{~S}_{2} \mathrm{O}_{3}$, $\mathrm{H}_{2} \mathrm{SO}_{5}, \mathrm{HSO}_{3} \mathrm{~F}$, and $\mathrm{HSO}_{3} \mathrm{Cl}$, Eur. J. Inorg. Chem. 2000 (2000) 2379-2386, doi: https://doi.org/10.1002/10990682(200011)2000:11<2379::AID-EJIC2379>3.0.CO;2-L.

68. R. Steudel, A. Prenzel, Raman spectroscopic discovery of the hydrogenthiosulphate anion, $\mathrm{HSSO}_{3}^{-}$, in solid $\mathrm{NH}_{4} \mathrm{HS}_{2} \mathrm{O}_{3}$, Z. Naturforsch. B44 (1989) 1499-1502, doi: https://doi. org/10.1515/znb-1989-1205.

69. F. A. Cotton, G. Wilkinson, Advanced Inorganic Chemistry A Comprehensive Text $4^{\text {th }}$ edition completely revised, John Wiley \& Sons, New Yor, 1980, str. 502-541.

70. A. N. Christensen, R. G. Hazell, A single-crystal X-ray structure determination of $\mathrm{Pb}_{3}\left(\mathrm{~S}_{2} \mathrm{O}_{3}\right)_{2}\left(\mathrm{CH}_{3} \mathrm{COO}\right)_{2}$, Acta Chem. Scand. 44 (1991) 1077-1079, doi: https://doi.org/10.3891/ acta.chem.scand.44-1077.

71. R. Steudel, Properties of sulfur-sulfur bonds, Angew. Chem. Int. Ed. Engl. 14 (1975), 655-720, doi: https://doi. org/10.1002/anie.197506551.

72. R. Steudel, Ermittlung von SS-Kernabständen aus Schwingungsspektren, Z. Naturforsch. B 30 (1975) 281-282, doi: https://doi.org/10.1515/znb-1975-3-431.

73. M. A. Cooper, F. C. Hawthorne, The structure topology of sidpietersite, $\mathrm{Pb}^{2+}{ }_{4}\left(\mathrm{~S}^{6+} \mathrm{O}_{3} \mathrm{~S}^{2-}\right) \mathrm{O}_{2}(\mathrm{OH})_{2}$, a novel thiosulfate structure, Can. Mineral. 37 (1999) 1275-1282.

74. G. K. Druschel, M. A. A. Schoonen, D. K. Nordstrom, J. W. Ball, Y. Xuc, C. A. Cohn, Sulfur geochemistry of hydrothermal waters in Yellowstone National Park, Wyoming, USA. III. An anion-exchange resin technique for sampling and preservation of sulfoxyanions in natural waters, Geochem. Trans. 4 (3) (2003) 12-19, doi: https://doi.org/10.1039/b211951j.

75. H. S. Kalal, M. Ghadiri, A. A. M. Beigi, S. A. S. Sadjadi, Simultaneous determination of trace amounts of sulfite and thiosulfate in petroleum and its distillates by extraction and differential pulse polarography, Anal. Chim. Acta 502 (2004) 133-139, doi: https://doi.org/10.1016/j.aca.2003.09.046.

76. URL: http://www.enciklopedija.hr/natuknica.aspx?id=61397 (14. 10. 2016.)

77. URL: http://www.pse.pbf.hr/hrvatski/_elementi/na/index. html\#OPCENITO (14. 10. 2016.)

78. P. L. McGeer, E. G. McGeer, M. Lee, Medical uses of sodium thiosulfate, J. Neurol. Neuromed. 4 (3) (2016) 28-30.

79. A. Šercer (ur.), Medicinska enciklopedija, Svezak 6 (Sol - Ž), Jugoslavenski leksikografski zavod, Zagreb, 1970, str. 158160. 
80. P. Bakker, H. Woerdenbag, V. Gooskens, B. Naafs, R. van der Kaaij, N. Wieringa, Dermatological preparations for the tropics: A formulary of dermatological preparations and background information on therapeutic choices, production and dispensing, 2nd revised edition, Beta Science Shop - University of Groningen, Groningen, 2012.

81. S. Nasi, H.-K. Ea, F. Lioté, A. So, N. Busso, Sodium thiosulfate prevents chondrocyte mineralization and reduces the severity of murine osteoarthritis, PLoS One 11 (7) (2016) e0158196 (16 str.), doi: https://doi.org/10.1371/journal. pone.0158196.

82. URL: http://ec.europa.eu/health/documents/community-register/2015/20150115130689/dec_130689_hr.pdf (14. 10. 2016.)

83. R. K. Bijarnia, M. Bachtler, P. G. Chandak, H. van Goor, A. Pasch, Sodium thiosulfate ameliorates oxidative stress and preserves renal function in hyperoxaluric rats, PLoS One $\mathbf{1 0}$ (4) (2016) e0124881 (16 str.), doi: https://doi.org/10.1371/ journal.pone.0124881.

84. S. Farese, E. Stauffer, R. Kalicki, T. Hildebrandt, B. M. Frey, F. J. Frey, D. E. Uehlinger, A. Pasch, Sodium thiosulfate pharmacokinetics in hemodialysis patients and healthy volunteers, Clin. J. Am. Soc. Nephrol. 6 (2011) 1447-1455, doi: https:// doi.org/10.2215/CJN.10241110.

85. E. van den Berg, A. Pasch, W. H. Westendorp, G. Navis, E. J. Brink, R. O. B. Gans, H. van Goor, S. J. L. Bakker, Urinary sulfur metabolites associate with a favorable cardiovascular risk profile and survival benefit in renal transplant recipients, J. Am. Soc. Nephrol. 25 (2014) 1303-1312, doi: https://doi. org/10.1681/ASN.2013050497.

86. S. Jin, H. Hyodoh, K. Matoba, F. Feng, A. Hayakawa, K. Okuda, K. Shimizu, S. Haga, M. Ozaki, K. Terazawa, Development for the measurement of serum thiosulfate using $\mathrm{LC}-\mathrm{MS} / \mathrm{MS}$ in forensic diagnosis of $\mathrm{H}_{2} \mathrm{~S}$ poisoning, Legal Med. 22 (2016) 18-22, doi: https://doi.org/10.1016/j.legalmed.2016.07.007

87. L. Stoffels, M. Krehenbrink, B. C. Berks, G. Unden, Thiosulfate reduction in Salmonella enterica is driven by the proton motive force, J. Bacteriol. 194 (2012) 475-485, doi: https:// doi.org/10.1128/JB.06014-11.

88. M. Iciek, L. Włodek, Biosynthesis and biological properties of compounds containing highly reactive, reduced sulfane sulfur, Polish J. Pharmacol. 53 (2001) 215-225.

89. Y. Saidu, Physicochemical features of rhodanese: A review, Afr. J. Biotechnol. 3 (2004) 370-374, doi: https://doi. org/10.5897/AJB2004.000-2071.

90. R. L. Morgan, J. L. Way, Fluorometric determination of cyanide in biological fluids with pyridoxal, J. Anal. Toxicol. 4 (1980) 78-81, doi: https://doi.org/10.1093/jat/4.2.78.

91. J. F. Read, S. A. Bewick, S. C. Donaher, M. D. Eelman, J. Oakey, C. Schaubel, N. C. Tam, A. Theriault, K. J. Watson, The kinetics and mechanism of the oxidation of inorganic oxysulfur compounds by potassium ferrate part II - tetrathionate ions, Biolnorg. React. Mech. 5 (2005) 265-280, doi: https://doi.org/10.1515/IRM.2005.5.4.265.

92. D. Lyons, G. Nickless, The lower oxy-acids of sulfur, u G. Nickless (ur.), Inorganic Sulfur Chemistry, Elsevier, Amsterdam, 1968, str. 509-533.

93. E. Freire, P. C. Christidis, P. J. Rentzerperis, A. Kirfel, G. Will, Experimental charge density in polythionate anions: II. $\mathrm{X}$-ray study of the electron density distribution in potassium tetrathionate, $\mathrm{K}_{2} \mathrm{~S}_{2} \mathrm{O}_{4}$, Z. Kristallogr. 188 (1989) 31-42, doi: https://doi.org/10.1524/zkri.1989.188.14.31.

94. E. Freire, S. Baggio, R. Baggio, M. T. Garland, Bis(1,10-phenanthroline- $\left.N, N^{\prime}\right)$ copper(II) tetrathionate and tris(1,10-phenanthroline- $\left.N, N^{\prime}\right)$ copper(II) tetrathionate pentahydrate, Acta
Cryst C 54 (1998), 464-468, doi: https://doi.org/10.1107/ S0108270197016284.

95. G. L. Rowe Jr., S. Ohsawa, B. Takano, S. L. Brantley, J. F. Fernandez, J. Barquero, Using crater lake chemistry to predict volcanic activity at Poás Volcano, Costa Rica, Bull. Volcanol. 54 (1992) 494-503, doi: https://doi.org/10.1007/ BF00301395.

96. Y. Xu, M. A. A. Schoonen, D. K. Nordstrom, K. M. Cunningham, J. W. Ball, Sulfur geochemistry of hydrothermal waters in Yellowstone National Park, Wyoming, USA. II. Formation and decomposition of thiosulfate and polythionate in Cinder Pool, J. Volcanol. Geotherm. Res. 97 (2000) 407-423, doi: https://doi.org/10.1016/S0377-0273(99)00173-0.

97. J. Zopfi, T. G. Ferdelman, H. Fossing, Distribution and fate of sulfur intermediates - sulfite, tetrathionate, thiosulfate, and elemental sulfur - in marine sediments, GSA Spec. Pap. 379 (2004) 97-116, doi: https://doi.org/10.1130/0-8137-23795.97.

98. D. Yu. Sorokin, A. Teske, L. A. Robertson, J. G. Kuenen, Anaerobic oxidation of thiosulfate to tetrathionate by obligately heterotrophic bacteria, belonging to the Pseudomonas stutzeri group, FEMS Microbiol Ecol. 30 (1999) 113-123, doi: https://doi.org/10.1111/j.1574-6941.1999.tb00640.x.

99. V. L. Barbosa-Jefferson, F. J. Zhao, S. P. McGrath, N. Magan, Thiosulphate and tetrathionate oxidation in arable soils, Soil Biol. Biochem. 30 (1998) 553-559, doi: https://doi. org/10.1016/S0038-0717(97)00177-6.

100.M. G. Aylmore, D. M. Muir, Thiosulfate leaching of gold a review, Miner. Eng.14 (2001) 135-174, doi: https://doi. org/10.1016/S0892-6875(00)00172-2.

101.S. E. Winter, P. Thiennimitr, M. G. Winter, B. P. Butler, D. L. Huseby, R. W. Crawford, J. M. Russell, C. L. Bevins, L. G. Adams, R. M. Tsolis, J. R. Roth, A. J. Bäumler, Gut inflammation provides a respiratory electron acceptor for Salmonella, Nature 467 (2010) 426-429, doi: https://doi.org/10.1038/ nature09415.

102.F. Blachier, A. M. Davila, S. Mimoun, P. H. Benetti, C. Atanasiu, M. Andriamihaja, R. Benamouzig, F. Bouillaud, D. Tomé, Luminal sulfide and large intestine mucosa: friend or foe?, Amino Acids 39 (2010) 335-347, doi: https://doi.org/10.1007/ s0072600904452.

103.Y. Chen, W. G. Junger, Measurement of oxidative burst in neutrophils, Methods Mol. Biol. 844 (2012) 115-124, doi: https://doi.org/10.1007/978-1-61779-527-5_8.

104.V. Narayan, A. K. Kudva, K. S. Prabhu, Reduction of tetrathionate by mammalian thioredoxin reductase, Biochemistry 54 (2015) 5121-5124, doi: https://doi.org/10.1021/acs.biochem.5b00620.

105.M. Price-Carter, J. Tingey, T. A. Bobik, J. R. Roth, The alternative electron acceptor tetrathionate supports B12-dependent anaerobic growth of Salmonella enterica serovar typhimurium on ethanolamine or 1,2-propanediol, J. Bacteriol. 183 (2001) 2463-2475, doi: https://doi.org/10.1128/ JB.183.8.2463-2475.2001.

106.B. Šimundić, Prehrambena roba: prehrana i zdravlje. Fakultet za turistički i hotelski menadžment, Opatija, 2008.

107.P. Keshavarz, J. Fathikalajahi, S. Ayatollahi, Mass transfer analysis and simulation of a hollow fiber gas-liquid membrane contactor, Iran. J. Sci. Technol. B 32 (2008) 585-599.

108.S. E. Manahan, Environmental Chemistry $7^{\text {th }}$ edition, Lewis Publishers, Boca Raton, FL, 2000.

109. B. Friedman, P. Brophy, W. H. Brune, D. K. Farmer, Anthropogenic sulfur perturbations on biogenic oxidation: $\mathrm{SO}_{2}$ additions impact gas-phase $\mathrm{OH}$ oxidation products of $\alpha$ - and $\beta$-pinene, Environ. Sci. Technol. 50 (2016) 1269-1279, doi: https://doi.org/10.1021/acs.est.5b05010. 
110.O. Rempillo, A. M. Seguin, A.-L. Norman, M. Scarratt, S. Michaud, R. Chang, S. Sjostedt, J. Abbatt, B. Else, T. Papakyriakou, S. Sharma, S. Grasby, M. Levasseur, Dimethyl sulfide air-sea fluxes and biogenic sulfur as a source of new aerosols in the Arctic fall, J. Geophys. Res. 116 (2011), D00S04, (15 str.), doi: https://doi.org/10.1029/2011JD016336.

111.URL: http://e-brojevi.udd.hr/220.htm (12. 8. 2016. )

112. N. L. Mathew, D. I. Schlipalius, P. R. Ebert, Sulfurous gases as biological messengers and toxins: comparative genetics and their metabolism in model organisms, J. Toxicol. 2011 (2011) 394970 (14 str.), doi: https://doi.org/10.1155/2011/394970.

113.J. Hong-fang, D. Shu-xu, Z. Xia, Z. Su-qing, T. Yue, B. Dingfang, T. Chao-shu, D. Jun-bao, Significance of endogenous sulfur dioxide in the regulation of cardiovascular system, J. Peking Univ. Health Sci. 39 (2007) 423-425.

114.J. G. McCoy, L. J. Bailey, E. Bitto, C. A. Bingman, D. J. Aceti, B. G. Fox, G. N. Phillips Jr., Structure and mechanism of mouse cysteine dioxygenase, Proc. Natl. Acad. Sci. USA 103 (2006) 3084-3089, doi: https://doi.org/10.1073/ pnas.0509262103.

115.X.-B. Wang, J.-B. Du, H. Cui, Sulfur dioxide, a double-faced molecule in mammals, Life Sci. 98 (2014) 63-67, doi: https://doi.org/10.1016/j.Ifs.2013.12.027.

116.Y. Huang, C. Tang, J. Du, H. Jin, Endogenous sulfur dioxide: A new member of gasotransmitter family in the cardiovascular system, Oxid. Med. Cell Longev. 2016 (2016) 8961951 (9 str.), doi: https://doi.org/10.1155/2016/8961951.

117.A. F. Voegele, T. Loerting, C. S. Tautermann, A. Hallbrucker, E. Mayer, K. R. Liedl, Sulfurous acid $\left(\mathrm{H}_{2} \mathrm{SO}_{3}\right)$ on lo? Icarus 169 (2004) 242-249, doi: https://doi.org/10.1016/j. icarus.2003.11.012.

118.B. Z. Shakhashiri, Chemical demonstrations - A handbook for teachers of chemistry volume 4, University of Wisconsin Press, Madison, WI, 1992.

119.D. A. Horner, R. E. Connick, Equilibrium quotient for the isomerization of bisulfite ion from $\mathrm{HSO}_{3}^{-}$to $\mathrm{SO}_{3} \mathrm{H}^{-}$, Inorg. Chem. 25 (1986) 2414-2417, doi: https://doi.org/10.1021/ ic00234a026.

120.E. D. Risberg, L. Eriksson, J. Mink, L. G. M. Pettersson, M. Yu. Skripkin, M. Sandström, Sulfur X-ray absorption and vibrational spectroscopic study of sulfur dioxide, sulfite, and sulfonate solutions and of the substituted sulfonate ions $\mathrm{X}_{3} \mathrm{C}$ $\mathrm{SO}_{3}{ }^{-}(\mathrm{X}=\mathrm{H}, \mathrm{Cl}, \mathrm{F})$, Inorg. Chem. 46 (2007) 8332-8348, doi: https://doi.org/10.1021/ic062440i.

121.S. Forsén, J. Kördel, Calcium in biological systems, u I. Bertini, H. B. Gray, S. J. Lippard, J. S. Valentine (ur.), Bioinorganic Chemistry, University Science Books, Mill Valley, CA, 1994, str. 107-166.

122.D. W. A. Bourne, T. Higuchi, I. H. Pitman, Chemical equilibria in solutions of bisulfite salts, J. Pharm. Sci. 63 (1974) 865-868, doi: https://doi.org/10.1002/jps.2600630612.

123.I. V. Pekov, N. V. Chukanov, S. N. Britvin, Y. K. Kabalov, J. Göttlicher, V. O. Yapaskurt, A. E. Zadov, S. V. Krivovichev, W. Schüller, B. Ternes, The sulfite anion in ettringite-group minerals: a new mineral species hielscherite, $\mathrm{Ca}_{3} \mathrm{Si}(\mathrm{OH})_{6}\left(\mathrm{SO}_{4}\right)$ $\left(\mathrm{SO}_{3}\right) \cdot 11 \mathrm{H}_{2} \mathrm{O}$, and the thaumasite-hielscherite solid-solution series, Mineralog. Mag. 76 (2012) 1133-1152, doi: https://doi.org/10.1180/minmag.2012.076.5.06.

124.L. Schropfer, Strukturelle Untersuchungen an $\mathrm{CaSO}_{3} \cdot 1 / 2 \mathrm{H}_{2} \mathrm{O}$,
Z. Anorg. Allgem. Chem. 401 (1973) 1-14, doi: https://doi. org/10.1002/zaac.19734010102.

125.J. A. Noblet, K. A. Schugart, Structures and relative stabilities of bisulfite ion isomers, J. Mol. Struct. Theochem 304 (1994) 1-11, doi: https://doi.org/10.1016/0166-1280(94)80001-4.

126.C. A. Miller, C. H. Lake, M. R. Churchill, J. D. Atwood, Reactivity studies of tricyclohexylphosphine $\left(\mathrm{PCy}_{3}\right)$. Square-planar iridium complexes with small gaseous molecules $\left(\mathrm{O}_{2}, \mathrm{H}_{2}, \mathrm{Cl}_{2}\right.$, and $\mathrm{SO}_{2}$ ). Molecular and crystal structure of $\operatorname{Ir}(\mathrm{CO})[\mathrm{OS}(\mathrm{O})$ $\mathrm{OH}]\left(\mathrm{SO}_{2}\right)\left(\mathrm{PCy}_{3}\right)_{2} \cdot \mathrm{C}_{6} \mathrm{H}_{6}$, the first structurally characterized oxygen-coordinated $\mathrm{SO}_{3} \mathrm{H}$ complex formed by insertion of $\mathrm{SO}_{2}(\mathrm{~g})$ into an $\mathrm{M}-\mathrm{OH}$ bond, Organometallics 14 (1995) 5442-5445, doi: https://doi.org/10.1021/om00011a072.

127.K. L. Carter, T. A. Siddiquee, K. L. Murphy, D. W. Bennett, The surprisingly elusive crystal structure of sodium metabisulfite, Acta Cryst. B 60 (2004) 155-162, doi: https://doi. org/10.1107/S0108768104003325.

128.A. Jain. P. Mathur, Estimation of sulphite levels in food products available in Delhi, India, J. Nutr. Food Sci. 6 (2) (2016) 1000463 (12 str.), doi: https://doi.org/10.4172/21559600.1000463

129.A. Isaac, C. Livingstone, A. J. Wain, R. G. Compton, J. Davis, Electroanalytical methods for the determination of sulfite in food and beverages, Trends Anal. Chem. 25 (2006) 589598, doi: https://doi.org/10.1016/j.trac.2006.04.001.

130.H. Vally, N. L. A. Misso, V. Madan, Clinical effects of sulphite additives, Clin. Exp. Allergy 39 (2009) 1643-1651, doi: https://doi.org/10.1111/j.1365-2222.2009.03362.x.

131. H. Vally, N. L. A. Misso, Adverse reactions to the sulphite additives, Gastroenterol. Hepatol. Bed Bench 5 (2012) 16-23.

132.F. Carbonero, A. C. Benefiel, A. H. Alizadeh-Ghamsari, H. R. Gaskins, Microbial pathways in colonic sulfur metabolism and links with health and disease, Front. Physiol. 3 (2012) 448 (11 str.), doi: https://doi.org/10.3389/fphys.2012.00448.

133.J. Bold, Considerations for the diagnosis and management of sulphite sensitivity, Gastroenterol. Hepatol. Bed Bench 5 (2012) 3-6.

134.I. Barić, M. Maradin, K. Fumić, Racionalna dijagnostika nasljednih metaboličkih bolesti, Paediatr. Croat. 48 (Supl 1) (2004) 155-159.

135.C. Kisker, H. Schindelin, A. Pacheco, W. A. Wehbi, R. M. Garrett, K. V. Rajagopalan, J. H. Enemark, D. C. Rees, Molecular basis of sulfite oxidase deficiency from the structure of sulfite oxidase, Cell 91 (1997) 973-983, doi: https://doi. org/10.1016/S0092-8674(00)80488-2.

136.P. A. Atwal, F. Scaglia, Molybdenium cofactor deficiency, Mol. Genet. Metab. 117 (2016) 1-4, doi: https://doi. org/10.1016/j.ymgme.2015.11.010.

137.M. Grings, A. P. Moura, A. U. Amaral, B. Parmeggiani, J. Gasparotto, J. C. F. Moreira, D. P. Gelaina, A. T. S. Wyse, M. Wajner, G. Leipnitz, Sulfite disrupts brain mitochondrial energy homeostasis and induces mitochondrial permeability transition pore opening via thiol group modification, Biochim. Biophys. Acta 1842 (2014) 1413-1422, doi: https:// doi.org/10.1016/j.bbadis.2014.04.022.

138. H. Mitsuhashi, Y. Nojima, T. Tanaka, K. Ueki, A. Maezawa, S. Yano, T. Naruse, Sulfite is released by human neutrophils in response to stimulation with lipopolysaccharide, J. Leukoc. Biol. 64 (1998) 595-599. 


\section{SUMMARY \\ Inorganic Sulphur Compounds in the Human Body. I. Oxo Compounds. \\ Sanja Stanković and Rudolf Kiralj*}

Sulphur is, after calcium and phosphorus, the most abundant element in the human body, where it can be found in numerous inorganic and organic compounds, and in very small amounts in elementary state. This review presents inorganic sulphur compounds from the class of endogenous oxo compounds present in the human body, which are primarily produced in enzymatic and non-enzymatic biosynthethic pathways in cells or in extracellular matrix. Sulphates, thiosulphates, $\mu$-disulphido-bis(trioxosulphates)(2-) (tetrathionates), sulphites, hydrosulphites, sulphonates and disulphites of the most abundant metals in the organism $\left(\mathrm{Na}^{+}, \mathrm{K}^{+}, \mathrm{Ca}^{2+}\right.$, and $\left.\mathrm{Mg}^{2+}\right)$ as well as sulphur dioxide, are described. The anions and $\mathrm{SO}_{2}$ are endogenous non-radical sulphur species which exist in significant concentrations in body fluids, in which they have specific physiological, pathological, metabolic, detoxifying, and other roles. They are mutually connected by metabolic pathways of sulphur compounds. While the sulphate ion is a common component of electrolytes and is a source of sulphur, the thiosulphate ion has several protective roles and is an important metabolite, and the anions produced by the reaction of $\mathrm{SO}_{2}$ with water are also important metabolic intermediates. Newer researches have identified roles of sulphur dioxide as a novel signal molecule, and of the anion $\mu$-disulphido-bis(trioxosulphate)(2-) as a metabolite generated in intestinal inflammation. Investigations on the described class of sulphur compounds and their roles in the human body are obviously not terminated and therefore, still may bring important and unexpected knowledge.

\section{Keywords}

Elemental sulphur, sulphates, thiosulphates, tetrathionates, sulphur dioxide, sulphites

Bjelovar University of Applied Sciences

Review

Trg Eugena Kvaternika 4

Received December 6, 2016

43000 Bjelovar, Croatia

Accepted February 22, 2017 